\title{
Chikungunya virus infection: molecular biology, clinical characteristics, and epidemiology in Asian countries
}

\author{
Sarawut Khongwichit ${ }^{1}$, Jira Chansaenroj ${ }^{1}$, Chintana Chirathaworn ${ }^{2,3}$ and Yong Poovorawan ${ }^{1 *}$
}

\begin{abstract}
Chikungunya virus (CHIKV) is a re-emerging mosquito-borne human pathogen that causes chikungunya fever, which is typically accompanied by severe joint pain. In Asia, serological evidence indicated that CHIKV first emerged in 1954. From the 1950's to 2005, sporadic CHIKV infections were attributed to the Asian genotype. However, the massive outbreak of CHIKV in India and the Southwest Indian Ocean Islands in 2005 has since raised chikungunya as a worldwide public health concern. The virus is spreading globally, but mostly in tropical and subtropical regions, particularly in South and Southeast Asia. The emergence of the CHIKV East/Central/South African genotype-Indian Ocean lineage (ECSA-IOL) has caused large outbreaks in South and Southeast Asia affected more than a million people over a decade. Notably, the massive CHIKV outbreaks before 2016 and the more recent outbreak in Asia were driven by distinct ECSA lineages. The first significant CHIKV ECSA strains harbored the Aedes albopictus-adaptive mutation E1: A226V. More recently, another mass CHIKV ECSA outbreak in Asia started in India and spread beyond South and Southeast Asia to Kenya and Italy. This virus lacked the E1: A226V mutation but instead harbored two novel mutations (E1: K211E and E2:V264A) in an E1:226A background, which enhanced its fitness in Aedes aegypti. The emergence of a novel ECSA strain may lead to a more widespread geographical distribution of $\mathrm{CHIKV}$ in the future. This review summarizes the current CHIKV situation in Asian countries and provides a general overview of the molecular virology, disease manifestation, diagnosis, prevalence, genotype distribution, evolutionary relationships, and epidemiology of CHIKV infection in Asian countries over the past 65 years. This knowledge is essential in guiding the epidemiological study, control, prevention of future CHIKV outbreaks, and the development of new vaccines and antivirals targeting CHIKV.
\end{abstract}

Keywords: Chikungunya virus, Outbreak, Asia, Novel ECSA, E1: K211E and E2:V264A

\section{Background}

Chikungunya virus (CHIKV) is a re-emerging mosquito-borne pathogen classified as a member of the Alphavirus genus in the family Togaviridae [1]. Infection by CHIKV typically results in mild and self-limiting disease in infected humans, characterized by fever, skin rash, myalgia, and arthralgia that can last weeks to

${ }^{*}$ Correspondence: yong.p@chula.ac.th

${ }^{1}$ Center of Excellence in Clinical Virology, Department of Pediatrics, Faculty of Medicine, Chulalongkorn University, Bangkok 10330, Thailand

Full list of author information is available at the end of the article months [2, 3]. Symptoms usually appear 4-7 days after exposure to CHIKV [4]. Although chikungunya fever is a self-limiting disease and the associated fatality rate is low, chikungunya-related death has been reported in young infants, the elderly, and people with pre-existing conditions such as cardiovascular disease, diabetes, kidney disease, and chronic liver disease [5-8]. An atypical clinical manifestation of CHIKV infection was associated with an increased mortality rate during the last chikungunya outbreak on the island of Réunion in the Indian Ocean in 2005-2006 [5]. This mass outbreak was associated with the CHIKV East/Central/ original author(s) and the source, provide a link to the Creative Commons licence, and indicate if changes were made. The images or other third party material in this article are included in the article's Creative Commons licence, unless indicated otherwise in a credit line to the material. If material is not included in the article's Creative Commons licence and your intended use is not permitted by statutory regulation or exceeds the permitted use, you will need to obtain permission directly from the copyright holder. To view a copy of this licence, visit http://creativecommons.org/licenses/by/4.0/. The Creative Commons Public Domain Dedication waiver (http://creativeco mmons.org/publicdomain/zero/1.0/) applies to the data made available in this article, unless otherwise stated in a credit line to the data. 
South African (ECSA) genotype harboring mosquito vector-adaptive mutations [9]. The adapted virus has subsequently threatened to undergo both endemic and epidemic spread in Africa, Asia, Europe, and America [10]. Ten years later, novel mutations in CHIKV were reported to have facilitated the second mass outbreak in South and Southeast Asia (Figs. 1 and 2) [11-15]. Here, we summarize the available reported data for CHIKV circulating in South and Southeast Asia and the available information on the history of CHIKV epidemiology, its molecular biology, clinical features, and genotypic distribution. This knowledge is important for understanding the epidemiology of CHIKV, and may lead to the development of novel approaches for controlling and preventing future outbreaks and guiding future research on the mechanisms underlying viral infections, as well as the development of new vaccines and antivirals targeting CHIKV.

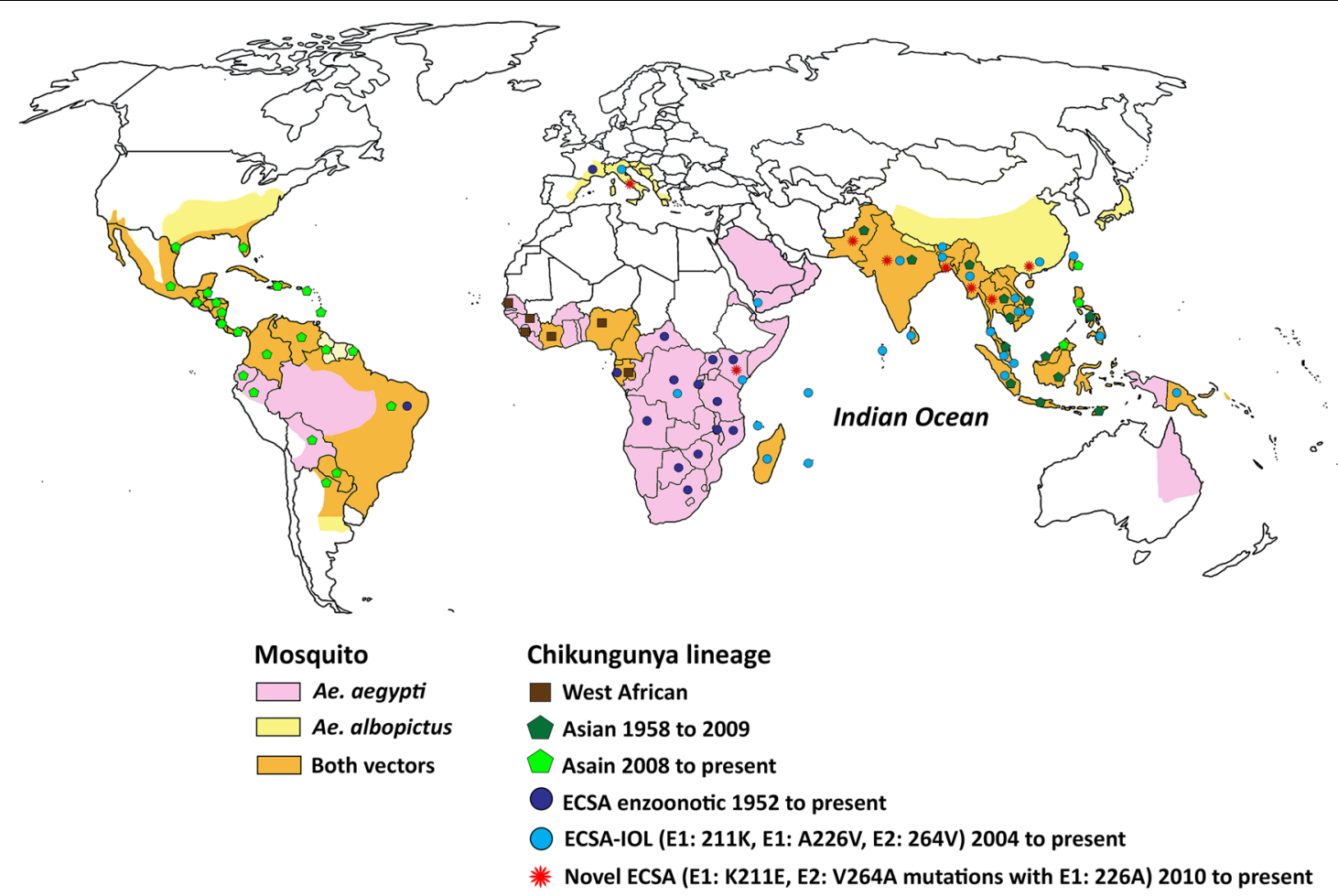

Fig. 1 Geographical distribution of CHIKV lineages during 1952-2020 and that of its primary mosquito vectors. Different CHIKV lineages are represented by distinct colored symbols. The map also shows the distribution of the primary CHIKV mosquito vectors. Areas shown in pink indicate the range of Ae. aegypti, those shown in yellow indicate the range of Ae. albopictus, and the range of both primary vectors is indicated in orange. The range of both primary vectors was obtained from [16]. Distribution of chikungunya virus data were obtained from a number of studies [9, 17-51]

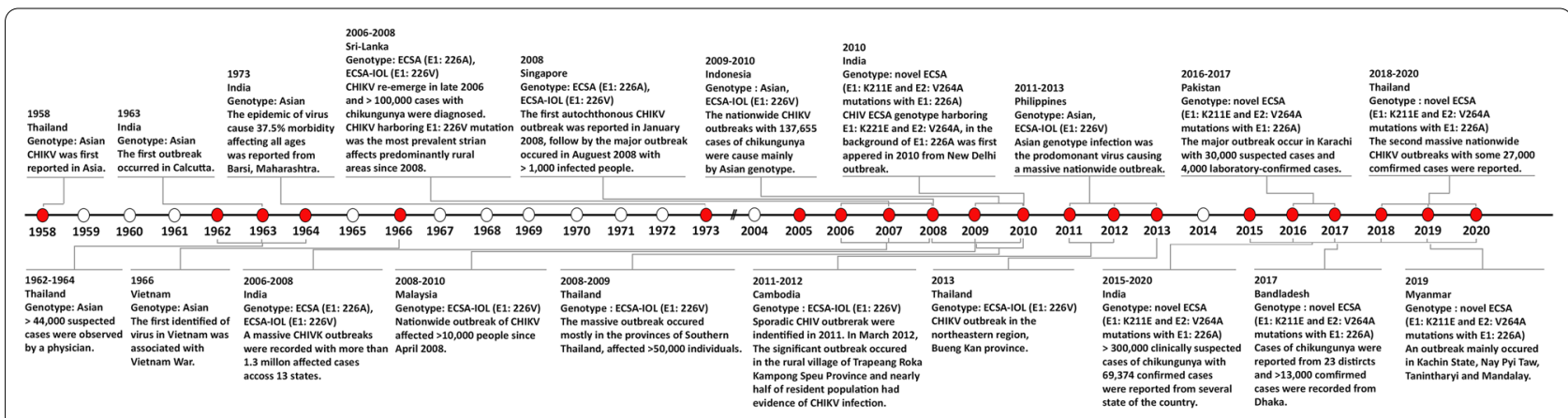

Fig. 2 Historical timeline of major CHIKV outbreaks in Asia (1958-2020) 


\section{Main text}

\section{The molecular structure and transmission cycle of CHIKV}

CHIKV has an enveloped, 60-70-nm diameter, icosahedral nucleocapsid containing a positive-sense singlestranded RNA genome of approximately $11.8 \mathrm{~kb}$. The genome comprises two open reading frames (ORFs), ORF1 and ORF2, flanked by a $5^{\prime}$ cap and a polyadenylated tail at the $3^{\prime} \mathrm{UTR}$. These ORFs encode polyprotein precursors of four nonstructural (nsP1, nsP2, nsP3, and nsP4) and six structural proteins (capsid [C]; envelope proteins E1, E2, and E3; 6K; and transframe proteins [TM]), respectively [52, 53]. CHIKV has been categorized into three major lineages: West African, Asian, and East/Central/South/Africa (ECSA). The Indian Ocean lineage (IOL) is a sub-lineage evolved from the ECSA lineage $[21,54]$. A comprehensive phylogenetic study of historic CHIKV strains indicated that the virus originated in Africa and has episodically spread into Asia in approximately 50-year intervals [55]. The IOL sub-lineage or ECSA-IOL genotype was emerged in Kenya in 2004 and then spread to several islands in the Indian Ocean, the Indian subcontinent, and Southeast Asia [56, 57]. In nature, CHIKV has both a sylvatic and an urban transmission cycle. CHIKV originated in Africa through a sylvatic cycle involving transmission between wild, nonhuman primates and forest-dwelling Aedes spp. mosquitoes, such as Ae. taylori, Ae. luteocephalus, Ae. furcifer, Ae. neoafricanus, and Ae. africanus (animal-mosquitoanimal) and was subsequently introduced into Asia [58$60]$. Virus transmission is mainly maintained in an urban cycle from human to human, with transmission occurring primarily via the bite of infected Ae. aegypti or Ae. albopictus [61-64].

\section{CHIKV pathogenesis and cellular tropism}

As noted previously, CHIKV infection is characterized by chronic and severe polyarthralgia and/or polyarthritis, which may persist for a week or several months. Polyarthralgia and/or polyarthritis can affect any joint but is most common in small joints, such as the ankles, wrists, and phalanges $[65,66]$. Studies have shown that animals and human patients suffering from persistent polyarthralgia induced by CHIKV infection display strong immune responses against the virus, such as the infiltration of immune cells (e.g., macrophages, natural killer [NK] cells, and $\mathrm{CD}^{+}{ }^{+} \mathrm{T}$ cells) into synovial tissues and increased secretion of pro-inflammatory mediators [67-69]. Elevated levels of interleukin 6 (IL-6) and granulocyte-macrophage colony-stimulating factor (GM-CSF) were shown to be correlated with an increased incidence of persistent joint pain, indicating that an association may exist between chronic arthritic symptoms and CHIKV infection [70].
CHIKV has broad cellular tropism and can infect a wide variety of cell lines and human primary cells in vitro, including human epithelial cell lines (Hela, HEK293, and HUH7), the human microglia cell line CHME5, human hepatocytes (HepG2 cells), a neuroblastoma cell line, primary fibroblasts (MRC5 lung cells), primary human skeletal muscle myoblasts (HSMMs), and monocytederived macrophages [71-75]. In nonhuman primates, macrophages were observed to serve as the primary cellular reservoirs of persistent CHIKV in the chronic phase of the disease [76].

\section{Cellular entry factors for CHIKV infection}

The host cell entry and attachment factors for CHIKV have been identified and characterized in insect and mammalian cells. The first characterized entry factor was prohibitin (PHB), which was shown to mediate the internalization of the virus into human microglial CHME-5 cells [77]. A potential CHIKV entry factor was also identified in the mosquito. ATP synthase $\beta$ subunit (ATPS $\beta$ ) was found to interact with envelope protein 2 (E2) of CHIKV in mosquito cells [78]. Matrix-remodeling-associated protein 8 (MXRA8) was the third entry factor to be characterized. This cell adhesion molecule was found to play a role as an entry factor for CHIKV and other alphaviruses, including O'nyong-nyong virus (ONNV), Ross River virus (RRV), and Mayaro virus (MAYV) [79-81]. Mice with Mxra8 gene defect show reduced levels of CHIKV infection, replication, and proinflammatory cytokines, including IL-6, MIP-1 $\beta$, GMCSF, and G-CSF [81]. However, residual CHIKV infection in mice lacking Mxra8, and the absence of a mosquito orthologue of Mxra8, indicate that additional as yet undiscovered host proteins mediate CHIKV entry into host cells. Some cell surface components, such as glycosaminoglycans (GAGs), serve as attachment factors for CHIKV [82-85]. Many pathogenic viruses utilize GAGs as attachment factors [82-84, 86-92]. Point mutations in domain A of the CHIKV E2 protein such as E79K, G82R, or E166K have been identified and exhibit enhanced GAG dependency but decreased in vivo replication [82, $83,93]$. These alterations influence the binding affinity of the virus by increasing the positive charge in domain $\mathrm{A}$ of the E2 protein [83]. Although GAGs promote CHIKV entry and replication, these cell surface proteins are not certainly required for infection, as CHIKV can still enter GAG-deficient cells [84]. Numerous studies have shown that phosphatidylserine-binding proteins, such as T-cell immunoglobulin and mucin (TIM)-1 and TIM4, function as a CHIKV attachment factors, enhancing CHIKV binding and entry into host cells [94-96]. Similarly, dendritic cell-specific intercellular adhesion molecule 3-grabbing nonintegrin (DC-SIGN) is an essential 
factor for enhancing the infectivity of alphaviruses such as CHIKV and Semliki Forest virus [97]. Additionally, DC-SIGN or CD209 gene polymorphisms appear to be associated with the clinical progression of chikungunya fever [98]. Furthermore, previous study have identified the interaction host protein partner of CHIKV E2 protein using a yeast two-hybrid assay with human brain cDNA library. Three candidate E2-binding protein partners were discovered, including actin, gamma 1 (ACTG1), protein tyrosine phosphatase, non-receptor type 2 (PTPN2), and collagen type 1 alpha 2 (COL1A2) [99]. Nevertheless, the precise roles played by ACTG1, PTPN2, and COL1A2 in $\mathrm{CHIKV}$ infection remain unclear. Although several proteins have been characterized as factors mediating the entry of CHIKV into host cells, interfering with the genes coding for these CHIKV entry factors does not fully inhibit viral infection and production, indicating that CHIKV employs multiple mechanisms to invade the host cells [100].

\section{Clinical symptoms and signs}

In Makonde, chikungunya means "that which bends up," and refers to the bent posture of CHIKV-infected patients with severe arthralgia [101]. Based on symptom duration, chikungunya infection is classified into three stages, namely, an acute stage (from around 3-7 days after exposure to the virus until the end of day 21), a postacute stage (after the first 3 weeks until the 3rd month after onset), and a chronic stage, which starts from 3 months after disease onset. After an incubation period of 3-7 days following a bite from a CHIKV-infected mosquito, most CHIKV infections become symptomatic, with the most common symptoms being acute febrile illness $\left(>38.9^{\circ} \mathrm{C}\right)$, arthralgia, rash, and headache [102, 103]. Acute symptoms usually resolve within 7 to 14 days [104, 105]. However, not all infections exhibit symptoms. Serosurveys revealed that $3-25 \%$ of individuals infected with CHIKV show no symptoms [106-108].

Severe arthralgia or joint pain is the main manifestation of chikungunya. The joint pain is most often symmetrical and polyarticular, affecting both small and large peripheral joints such as the wrists, elbows, ankles, knees, hands, feet, and shoulders [103]. CHIKV infection can lead to severe joint pain with or without arthritis and last for several months to years in the chronic stage $[65,66]$. Persistent arthralgia in chikungunya is frequently debilitating, resulting in an impaired quality of life $[109,110]$. The prevalence of chikungunya-associated patients progressing to a chronic stage has been reported to range between 4.1 and $78.6 \%$; however, the reasons for this variability remains unclear $[111,112]$. The possibility of chronic consequence may be due to persistent virus infection, tissue injury caused by a viral infection, exacerbation of a pre-existing joint condition, and genetic susceptibility [113-115]. Even though chikungunya infection rarely progresses to a severe or life-threatening form, atypical clinical symptoms of chikungunya, such as cardiovascular and neurological manifestations, can promote a significant increase in morbidity. A wide variety of chikungunya-associated neurological manifestations have been reported, such as encephalitis, myelopathy, peripheral neuropathy, myelitis, and meningoencephalitis [116-119]. Death from chikungunya disease is infrequent and results mainly due to existing health problems or severe clinical manifestation in the elderly, infants, or immunocompromised patients [120-122].

\section{Diagnosis of CHIKV}

As with other arbovirus infections, individuals infected with chikungunya can present a broad spectrum of symptoms, including high fever, headache, skin rash, myalgia, arthralgia, and neurological complications [3, 123]. The overlapping symptoms of chikungunya and other arbovirus diseases make diagnosis based on clinical symptoms alone challenging, particularly when CHIKV is co-circulating in the areas in which DENV and ZIKV are endemic $[124,125]$. Thus specific laboratory diagnosis is necessary to validate the differential diagnosis of chikungunya and other etiologic agents of the disease [126]. The laboratory diagnosis of CHIKV infection is accomplished by examining the plasma or serum of suspected patients. Several methods are used to identify CHIKV, including viral isolation using cell culture and viral nucleic acid detection by reverse transcription-polymerase chain reaction (RTPCR) and detection of CHIKV-specific IgM antibodies using a serological assay [127, 128]. The laboratory diagnostic testing algorithm to confirm CHIKV infection developed by the Center for Disease Control and Prevention $(\mathrm{CDC})$ is dependent on disease characteristics and the timing of sample collection. RT-PCR can generally be used to detect viral RNA in the 1st week after the onset of symptoms, while an enzyme-linked immunosorbent assay (ELISA) is used as the serological test for the detection of CHIKV-specific IgM antibodies [129]. The sensitivity of detection of these antibodies in chikungunya patients increases for samples collected beginning after approximately 5 days of illness [130]. However, false-positive results can occur due to cross-reactivity with other arboviruses. In particular, antibody cross-reactions with DENV and the Semliki Forest antigenic complex group, such as Mayaro and o'nyong-nyong, have been observed [131-134]. Although viral culture is the gold standard for the diagnosis of CHIKV infection, the isolation of infectious CHIKV in cell culture from a patient's blood is generally used as a research tool rather than for routine diagnostic purposes. Viral culture for CHIKV detection 
shows the greatest sensitivity in the viremia phase, typically within 5 days after disease onset [135].

\section{History of CHIKV emergence and re-emergence}

The earliest detailed description of CHIKV appeared in 1952 during an outbreak in Tanzania. CHIKV was first isolated from a febrile patient in this country in early 1953 [136]. Since 1954, CHIKV has disseminated from its origin throughout Asian countries, including Thailand (1958), Cambodia (1961), Vietnam (1967), Myanmar (1975), Sri Lanka (1969), and India (1963) [137-142]. The virus has also been moving further east in the Pacific, including to the Philippines and Indonesia [143, 144]. In Asia, CHIKV was first isolated from the sera of patients in Bangkok, Thailand, in 1958, and this isolate was classified as an Asian genotype [138]. The first significant reported urban outbreak in Bangkok was recognized in the 1960s. During the period 1962-1964, rates of CHIKV infection in the Bangkok area were dramatically high, with an estimated 44,000 suspected cases of CHIKV infection, including two reports of encephalitis [145-149]. In India, the first CHIKV outbreak occurred in 1963 in Calcutta. Clinically, the patients presented with atypical symptoms, including hemorrhagic manifestations and neurological complications, with deaths also being documented. In the 1973 outbreak in India, the morbidity rate was reported to be $37.5 \%$ in Barsi, Maharashtra state. These CHIKV outbreaks were caused by the Asian genotype [150, 151]. Before 2000, CHIKV epidemics were mainly sporadic and limited to Africa and Asia; however, since 2000, CHIKV outbreaks have become more frequent. Extensive evidence, including molecular genetic evidence, indicates that $\mathrm{CHIKV}$ may have evolved adaptations to new mosquito vectors [9, 152]. Following the virus outbreak on the Kenyan coast between 2004 and 2005, the outbreak spread rapidly to several islands of the Indian Ocean, India, Sri Lanka and Southeast Asia, resulting in millions of infected people [152, 153]. During the mass outbreak on La Réunion in the southwestern part of the Indian Ocean, the surveillance system estimated 244,000 people (35\% of the population) were affected by chikungunya, and high levels of excess deaths were associated with CHIKV infection $[23,154,155]$. Many studies have indicated that an $A e$. albopictus-competent CHIKV strain was responsible for the mass chikungunya outbreak in La Réunion Island in 2005-2006 [156-158]. Remarkably, sequencing and evolutionary analysis of CHIKV isolates from La Réunion Island and other islands in the Indian Ocean suggested that the epidemic was associated with a strain of CHIKV harboring a single mutation in the viral envelope protein (E1: A226V) that was derived from the ECSA genotype (the IOL). This single amino acid substitution facilitated
CHIKV transmission by Ae. albopictus, but not by Ae. aegypti $[9,57]$, indicating that Ae. albopictus was the primary transmission vector in the La Réunion outbreak. The number of epidemics associated with this vector subsequently increased worldwide, both locally and in new geographical areas (Africa, Europe, and Asia) where Ae. albopictus is widespread. However, local transmission was not detected in America until 2013; the etiologic agent was a strain of the Asian lineage [159].

\section{India}

The first recorded outbreak of CHIKV in India was reported in Kolkata, West Bengal, in 1963 [160, 161]. This was followed by a number of other outbreaks in Tamil Nadu, Andhra Pradesh, and Maharashtra during 19641965 [162]. The virus virtually disappeared from India after the last reported outbreak during the twentieth century was documented in Maharashtra in 1973 [150]. The circulating virus that caused outbreaks in India until the 1970s was reportedly the Asian genotype [163]. After a gap of 32-years, CHIKV re-emerged in the country and caused a massive outbreak between late 2005 and 2008 . The causative CHIKV strain was of the ECSA lineage. More than 1.3 million cases of CHIKV infection were documented in almost every Indian state, including Karnataka, Madhya Pradesh, Andhra Pradesh, Tamil Nadu, and Maharashtra [36, 151, 164]. Phylogenetic analysis of CHIKV isolates obtained from 2006 demonstrated that the Indian CHIKV strain isolated in 2006 was more evolutionarily related to the viral strain from East Africa and the Indian Ocean islands but did not harbor the adaptive E1: A226V mutation [165]. Nevertheless, acquisition of the E1: A226V substitution was later observed in the southern Indian state of Kerala in 2007. In 2007, Kerala was the worst-affected state in the country, accounting for $55.8 \%$ of suspected chikungunya cases. High abundance of $A$. albopictus in the rubber plantations region of Kerala may have contributed significantly to the explosive spread of CHIKV in this state $[28,166,167]$.

\section{Sri Lanka}

CHIKV re-emerged in October 2006 after a hiatus of 40 years. During 2006-2007, over 100,000 cases of CHIKV infection were diagnosed $[168,169]$. The early chikungunya cases that arose predominantly in the dengue-endemic urban area and coastal towns during 2006-2007 were identified as an E1: 226A-carrying strain of the ECSA lineage. In 2008, CHIKV spread primarily in the rubber and banana plantation areas, which have high densities of Ae. albopictus. Most of the 2008 CHIKV Sri Lankan isolates possessed the E1: A226V substitution, which increased virus replication and dissemination in Ae. albopictus. Reports from Sri Lanka and Singapore 
also indicated that the strain responsible for the significant outbreaks in Sri Lanka, Singapore, and Malaysia were more genetically related to the Indian CHIKV isolates than to the Indian Ocean isolates [26].

\section{Bangladesh}

In Bangladesh, the first confirmed case of CHIKV infection in humans was documented in 2008 and was based on serologic evidence. The first recognized outbreak occurred in the northwest part of Bangladesh near the border with India [170]. In 2009, an epidemic of CHIKV with restricted geographic spread was detected in Santhia Upazila [171]. Other small-scale outbreaks of CHIKV were reported in rural areas in 2011 [172] and 2012 [173]. Phylogenetic analysis of the whole genome of CHIKV indicated that the CHIKV strain isolated in 2011 belonged to the ECSA-IOL genotype, forming a cluster with Indian CHIKV strains from 2009 [174]. Since then, reports of sporadic cases and small-scale outbreaks of CHIKV continued from 2013 to 2016 [171, 175].

\section{Pakistan}

CHIKV is likely to have been present for several decades as CHIKV-specific antibodies were identified in rodents and a few humans as long ago as 1983 [176]. In 2011, three cases of chikungunya were reported during the dengue virus outbreak in Lahore, Pakistan [177].

\section{Malaysia}

Malaysia has also experienced CHIKV outbreaks of both the Asian and ECSA genotypes. The first outbreak occurred in Port Klang, with more than 51 people being infected between December 1998 and February 1999 [178]. The Asian genotype was responsible for the first outbreak. The second CHIKV outbreak, which occurred between March and April 2006, affected over 200 people in Bagan Panchor. Notably, although this outbreak in Malaysia coincided with the global outbreak associated with the ECSA genotype, evidence showed that the second outbreak was driven by the endemic Asian lineage [179]. The third outbreak in December 2006 in Ipoh, Perak, resulted from the import of the ECSA genotype from India [180]. These first three outbreaks were relatively limited in scale, restricted as they were to a single area affecting approximately 300 people. Between April 2008 and 2010, a nationwide CHIKV outbreak was recorded in 14 out of 15 states and federal territories in Malaysia, with some 10,000 people affected. Sequence analysis revealed that an ECSA strain harboring the adaptive E1: A226V mutation was responsible for this extensive nationwide outbreak [27].

\section{Singapore}

In Singapore, although the country has experienced dengue transmission since 1960 [181], the first case of locally transmitted CHIKV infection was only reported in January 2008 [182]. A significant CHIKV outbreak occurred in Singapore in July 2008, leading to over 1000 infections, and was associated with the circulation of both the wild-type (226A) and mutant (A226V) E1-carrying CHIKV belonging to the ECSA. Phylogenetic tree analysis grouped CHIKV strains isolated from May to July 2008 with Malaysian isolates [183]. During 20102012, only sporadic cases were reported in Singapore. In 2013, Singapore again experienced a significant outbreak involving 1059 laboratory-confirmed cases of chikungunya infection [184].

\section{Thailand}

A significant outbreak in Thailand during 2008-2009 was also driven by CHIKV of the ECSA-IOL, resulting in the infection of approximately 54,000 individuals. The outbreak occurred in at least 58 , mostly southern, provinces of Thailand, including Narathiwat, Phuket, Phatthalung, Songkhla, Pattani, Yala, Surat Thani, Phangnga, and Nakhon Si Thammarat $[185,186]$. In 2010, a total of 1565 cases of CHIKV infection were reported in Thailand. In the ensuing 3 years, circulating CHIKV ECSA-IOL strains in the country caused an outbreak in Bueng Kan province in northeast Thailand [187]. Phylogenetic studies suggested that CHIKV strains isolated during the early and late 2008-2009 outbreak belonged to the ECSA genotype and were most closely related to CHIKV isolates detected in India in 2007 and Singapore in 2008 [188]. However, previously the predominant circulating strains of CHIKV in Thailand were of Asian genotype [21, 138, 188]. In addition, there is evidence that banked serum samples from five patients affected in 2009 also indicated the involvement of the Asian genotype of CHIKV. Among these samples, the E1 sequence of CHIKV isolated from patient serum collected from Songkhla Province, Thailand, exhibited $100 \%$ identity to the 2010 Indonesian isolate (CHIK/SBY8/10 isolate, GenBank Accession number AB678677) [189].

\section{Myanmar}

In Myanmar, all CHIKV strains isolated in 2010 from patients displaying dengue-like syndromes belonged to the ECSA-IOL genotype. The isolates were phylogenetically grouped with the 2008 Malaysia isolate, 2009 Thailand isolates, and 2010 China isolates [190]. 


\section{Cambodia}

CHIKV epidemic was reported in 1961, possibly as a result of the emergence of a CHIKV strain of Asian lineage [191]. In 2011, CHIKV of the ECSA-IOL emerged in Cambodia, with all the isolates from this outbreak being closely related to the strain that caused the outbreak in southern Thailand in 2008-2009 [192] and a small outbreak in Vietnam in 2012 [193].

\section{Lao}

Lao, which borders Cambodia, has reported sporadic CHIKV outbreaks in the provinces near the border between the two countries. Although the mosquito vectors Ae. albopictus and Ae. aegypti are present in the country, no cases of CHIKV infection were documented in Lao until 2012, when the first proven case of CHIKV was reported and resulted from the importation of the Cambodian strain of the virus $[194,195]$.

\section{Vietnam}

Chikungunya was first described in the 1960s [196]. The appearance of chikungunya was associated with the Vietnam War [140]. At that time, the most common genotype was the Asian genotype [22]. Although Vietnam borders countries where CHIKV outbreaks have occurred, including Thailand and Cambodia, only four sporadic cases $(4 / 5,617 ; 0.07 \%)$ were identified in a retrospective study of serum samples collected between October 2010 and December 2014 from patients under 16 years of age with acute fever of less than 3 days. The four CHIKV isolates were of the IOL within the ECSA genotype, and were closely related to the 2011 Cambodian strain [193]. Further surveillance of CHIKV infection in patients hospitalized $(\mathrm{N}=558)$ in Vietnam with acute febrile illness from September 2012 to September 2014 failed to identify cases of CHIKV infection. However, CHIKV was detected in two mosquitoes (Ae. aegypti) collected from Dac Nong and Long An province [197].

\section{Republic of the Philippines}

In the Philippines, CHIKV was first isolated in 1965 [198]. Sporadic cases were documented in Cebu, Masbate, and Mindanao islands in 1986 [199] and Cavite and Luzon in 1996 [107]. During 2011-2013, there was an extensive nationwide outbreak due mainly to the CHIKV Asian genotype. The co-circulation of the Asian genotype and the ECSA-IOL harboring E1: A226V was detected during 2011-2013. Nevertheless, the spread of the ECSA-IOL genotype was limited to the southern provinces of Mindanao. The transmission of both Asian and ECSA-IOL genotypes during the nationwide outbreak resulted from the movement of people near the country's border [200].

\section{Indonesia}

According to official reports from the Ministry of Health of the Republic of Indonesia, chikungunya cases were formally reported for the first time in Samarinda, East Kalimantan, in 1973 [201, 202]. However, a serological survey of CHIKV infections demonstrated that the first occurrence of chikungunya was in 1964 [203]. In 1982, a CHIKV outbreak was virologically confirmed in Jambi, South Sumatra [144]. Subsequently, frequent CHIKV outbreaks were documented between 1982 and 1985 throughout the country [144, 204]. After a hiatus of nearly two decades, CHIKV re-emerged, and was responsible for at least 24 probable outbreaks throughout Indonesia from September 2001 to March 2003 [205]. In 2009-2010, there was a significant nationwide outbreak of the virus, during which 137,655 CHIKV people were infected. Based on sequencing and evolutionary analysis, most of the Indonesian isolates were characterized as Asian genotypes, and the rest as ECSA genotypes. The Indonesian ECSA genotype was first identified in May 2008. The Indonesian ECSA isolates in 2008 and 2011 appear to have been most closely related to the ECSA viruses that caused the massive outbreaks in Southeast Asian countries during the same period [206].

\section{The emergence of a novel sub-lineage of ECSA chikungunya virus}

The CHIKV outbreaks that occurred in Asia between 1960 and 1999 were caused by Asian genotypes. Affected countries included India and Pakistan in South Asia and Thailand, Malaysia, Cambodia, Myanmar, Vietnam, Indonesia, and the Philippines in Southeast Asia [22]. Nevertheless, the explosive CHIKV outbreaks in the Indian Ocean Islands that have occurred since 2005 and the global increase in transportation have altered the distribution of circulating CHIKV genotypes. Different CHIKV ECSA lineages, especially the ECSA-IOL, have expanded locally and also spread to new regions of the Indian Ocean [207], Asia [41, 169, 183, 188, 208, 209], and Europe [24, 210]. Since 2016, the emergence of a unique CHIKV ECSA genotype-associated molecular signature has been reported from several parts of the world [12, 46, 211-213]. The genome of the new distinct CHIKV ECSA lineage contains two novel mutations-E1: K211E and E2: V264A-in a wild-type E1: 226A background. This lineage was mostly responsible for outbreaks in the Indian subcontinent $[12,14,214]$ and Southeast Asia [15, 215] (Fig. 3). The E1-K211E mutation first appeared in India in late 2009, as evidenced by isolate AP0109 (HM159390) from Hyderabad [216]. In 2010, a CHIKV strain harboring two novel mutations, E1: K211E and E2: V264A, was detected in all CHIKV isolates from New Delhi, India [44]. Furthermore, two new 


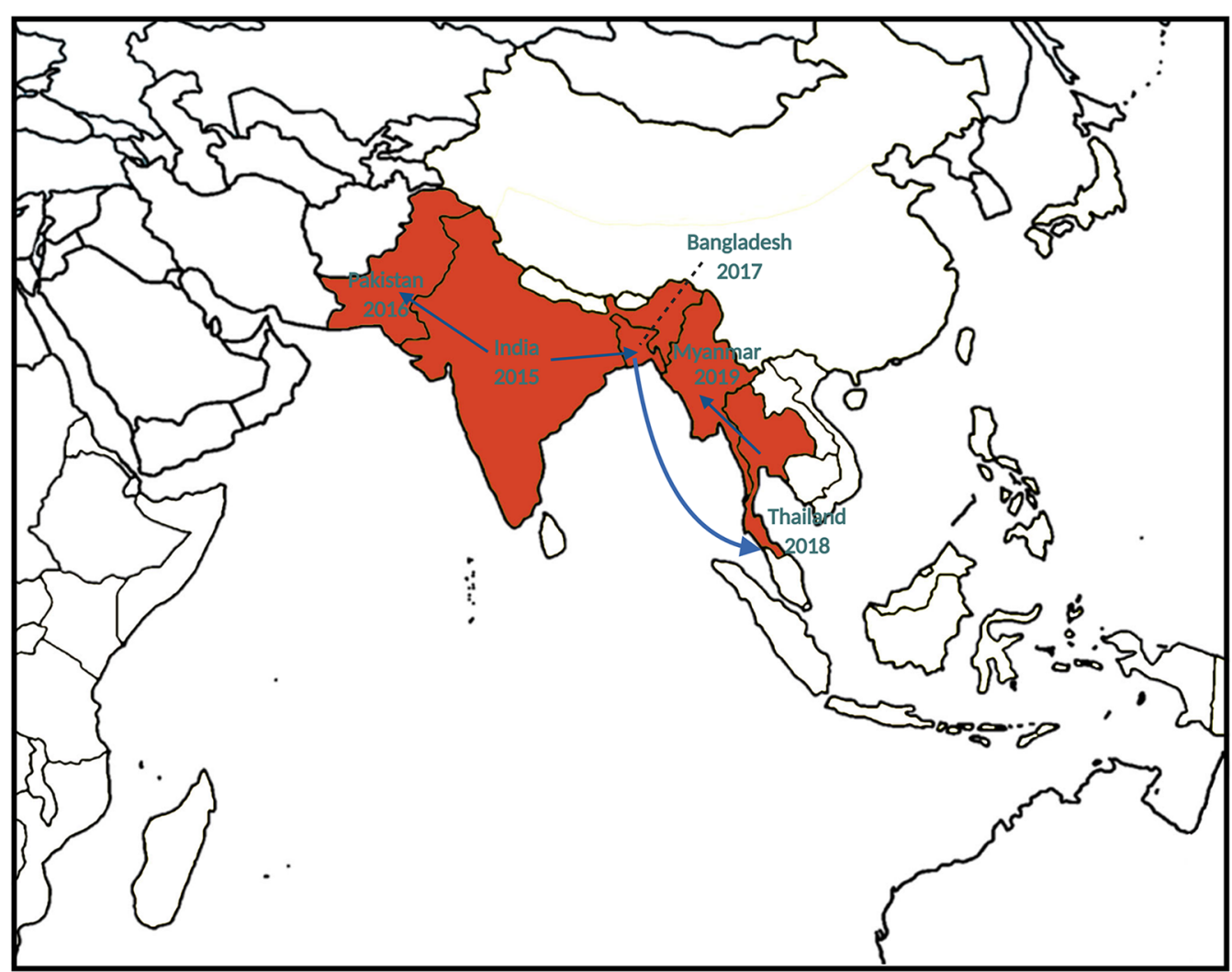

Fig. 3 Distribution and spread of the novel sub-lineage of CHIKV East/Central/South African (ECSA) genotype in South and Southeast Asia during 2015-2019. CHIKV Chikungunya virus, ECSA East/Central/South African genotype

mutations, E1: K211E and E2: V264A, were identified in Ae. aegypti-dominated regions in Tamil Nadu [216] and Kolkata [217] in 2011 and 2012, respectively. An evolutionary analysis of the CHIKV ECSA lineage from 1953 to 2020 has been undertaken, and is shown in Fig. 4. The substitution of amino acid residue 211 of the E1 glycoprotein from lysine (K) to glutamic acid (E) is under positive selection pressure [216]. In contrast, no evidence has been found of positive selection for the substitution of amino acid residue 264 (V264A) of the E2 glycoprotein. The double-mutant virus containing E1: K211E and E2: V264A and lacking the A226V substitution enhanced the rates of infection, dissemination, and transmission of CHIKV in the Ae. aegypti vector when compared with those of CHIKV of the ECSA genotype with wild-type
E1: 226A [218]. However, these double mutations did not have a significant effect on CHIKV fitness for Ae. albopictus. Here, we compile documents of CHIKV outbreaks in different countries of South Asia and Southeast Asia since 2015.

\section{An outbreak in 2015-2017 in India}

According to the National Vector Borne Disease Control Programme (NVBDCP), India reported 27,553 suspected cases and 3342 laboratory-confirmed cases of CHIKV infection in 2015. Most (75\%) of the suspected cases of CHIKV infection were in Karnataka. The number of chikungunya cases continued to grow into 2016, when there were 64,057 suspected cases, $41.2 \%$ of which were diagnosed with CHIKV infection. A total of $55.4 \%$

Fig. 4 Evolutionary analysis of the complete genome of the CHIKV ECSA lineage. Bayesian time-scale tree of 169 genomes of the CHIKV ECSA lineage based on the strict clock model. The 95\% HPD values of the most recent common ancestors (tMRC) are shown beside the nodes. The colored square of each strain corresponds to the amino acid mutations specific for the CHIKV ECSA lineage. CHIKV chikungunya virus, ECSA East/ Central/South African, HPD highest posterior density 


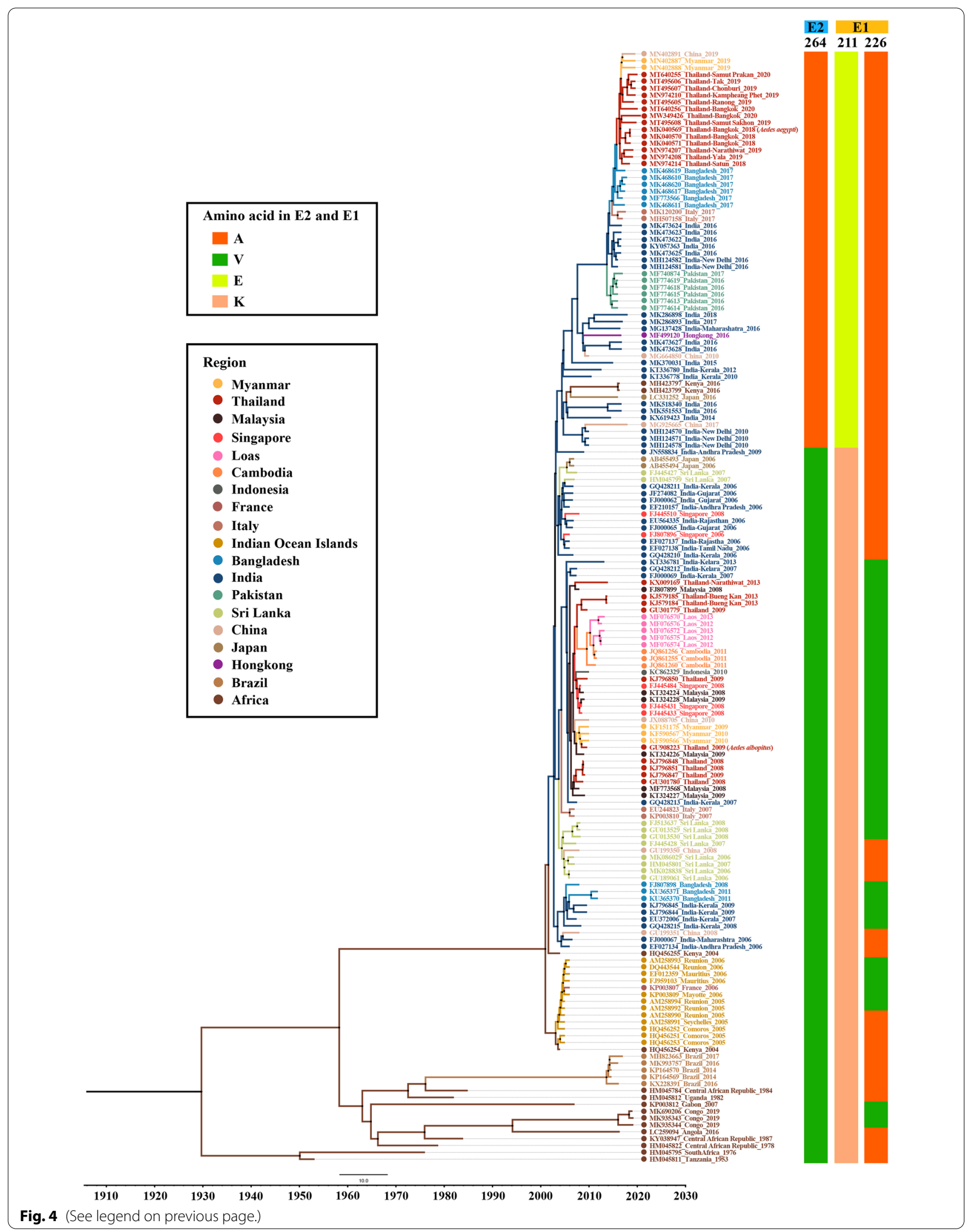


of all the suspected cases and $53.9 \%$ of all the confirmed cases originated from three states in India, namely, New Delhi, Maharashtra, and Karnataka [219]. In 2017, a total of 67,769 suspected chikungunya cases were reported from states throughout the country. Remarkably, the A. albopictus-adaptive E1: A226V mutation, which has been responsible for the outbreaks in the Indian Ocean Islands and India since 2007 [28], was absent in recent Indian isolates. The 2015-2017 Indian isolates harbored A. aegypti-adaptive E1: K211E and E2: V264A mutations, in conjunction with wild-type E1: 226A. The current re-emergence of CHIKV strains possessing unique mutations in CHIKV E1, such as K16E/Q, K132Q/T, and S355T; and in CHIKV E2, such as C19R and S185Y, could be related to epitopes or virulence-determining domains [12]. During 2018-2020, India recorded more than 170,000 suspected and 27,120 confirmed cases in various states of the country [219].

\section{An outbreak in 2017 in Bangladesh}

From April 2017 to September 2017, Bangladesh experienced a significant outbreak of CHIKV, during which numerous chikungunya cases were documented in 23 districts [220]. Moreover, CHIKV rapidly spread throughout the capital city, Dhaka, which has more than 18 million inhabitants, resulting in over 13,000 clinically confirmed cases [221]. Although this recent outbreak in 2017 was driven by the CHIKV ECSA genotype, this isolate was genetically distant from the isolate responsible for the previous outbreak. Comprehensive phylogenetic analyses revealed that the strains from the 2017 outbreak formed a novel cluster within the ECSA with the 2016 South Asian strains, including the 2016 India isolate and the 2016 Pakistan isolate, suggesting that they represented a novel sub-lineage of the ECSA genotype [14]. The 2017 Bangladesh strains possessed two novel mutations, E1: K211E and E2: V264A, but lacked the E1: A226V substitution. Moreover, a novel I317V adaptive mutation identified in a 2017 Bangladesh isolate was also found in a southern Indian strain isolated during 20152016 [222] and a 2016-2017 strain isolated in the Central India [48].

\section{An outbreak in 2016-2017 in Pakistan}

Following the large CHIKV outbreak in India in 2016, a significant upsurge of CHIKV infection was documented in Karachi, which is adjacent to India; this spate started in November 2016, leading to over 30,000 suspected chikungunya cases, 4000 of which were laboratory confirmed [214]. Sequence analysis indicated that the current Pakistani strains lack the Ae. albopictus-adaptive E1: A226V and E2: K252Q mutations.
Phylogenetic and migration analysis revealed that the 2016 outbreak in Pakistani occurred due to the importation of the virus strain from India [223]. A chikungunya outbreak occurred across the country from December 2016 to May 2017 [224]. The ECSA genotype caused the 2016-2017 outbreak in Pakistan. Whole-genome sequencing and phylogenetic analyses of CHIKV genotypes circulating in Pakistan during 2016-2017 revealed that the 2016-2017 Pakistan outbreak virus possessed two novel mutations, E1: K211E and E2: V264A, in the background of E1: 226A, which belongs to a cluster of novel ECSA [46, 212, 225].

\section{An outbreak in 2018-2020 in Thailand}

A second massive CHIKV outbreak started in late 2018 in the south of Thailand. The virus spread nationwide, and over 27,000 confirmed cases were documented between 2018 and 2020. According to the Bureau of Epidemiology, Ministry of Public Health, Thailand (Fig. 5) [186], monthly reported chikungunya cases started to rise in June 2018. All the initial cases were associated with individuals residing in Satun and Narathiwas provinces in the south of Thailand. The number of reported cases rose continuously from $<20$ cases per month between January and May to 1171 and 1759 cases in November and December 2018, respectively. In 2019, chikungunya cases were reported in 60 provinces of the country, but most were from Bangkok and provinces in the south of Thailand. From January to November 2020, the outbreak was reported in 72 provinces across the country. Most of the cases of CHIKV infection were documented in Chanthaburi and several provinces in the north. Overall, chikungunya-associated morbidity rates in Thailand in 2018,2019 , and 2020 were $5.40,19.73$, and 15.69 per 100,000 population, respectively. The causative CHIKV strains of the second mass outbreak in Thailand belonged to the ECSA; however, these ECSA strains lacked the valine substitution at position 226 of CHIKV E1 and were grouped into a new distinct sub-lineage separate from ECSA-IOL CHIKV isolates of the previous outbreak during 2008-2009. The 2018-2020 Thai strains possesses two novel mutations, E1: K211E and E2: V264A, in the E1: 226A background [15, 47]. Genomic and phylogenetic analyses revealed that the 2018-2020 CHIKV strains isolated in Thailand were similar to the strains that caused the recent outbreak in South Asia during 2016-2017, but not to the causative agent of the first massive outbreak in the country that occurred in 2008-2009. The 2018-2020 Thai strains showed the greatest homology to sequences from Bangladesh, indicating that these viral strains were imported into Thailand from Bangladesh before becoming the local transmission cause [47]. 

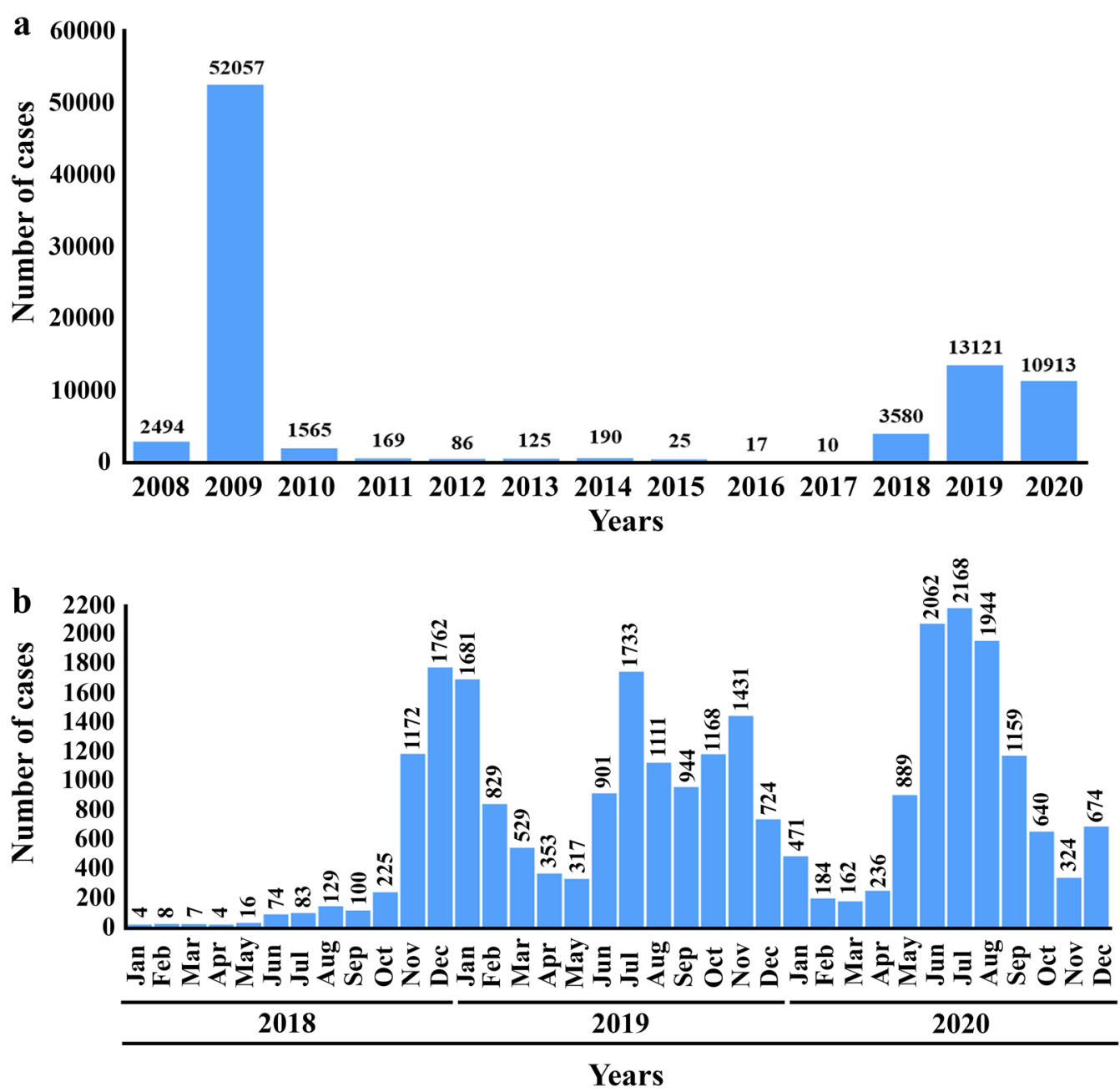

Fig. 5 Chikungunya cases in Thailand. a The number of chikungunya cases per year between 2008 and 2020. b The monthly number of chikungunya cases in Thailand between 2018 and 2020

\section{An outbreak in 2019 in Myanmar}

Following an outbreak of chikungunya in 2010 [190], no cases of CHIKV infection were officially documented in Myanmar until 2019. Recently, CHIKV outbreaks were reported in Kachin State, Nay Pyi Taw, Tanintharyi, and the Mandalay region [226]. The CHIKV from the 2019 outbreak in Myanmar was a new ECSA strain; this CHIKV strain lacked the E1: A226V substitution and harbored the E1: K211E mutation, whereas the ECSA-IOL with E1: $226 \mathrm{~V}$ mutation caused the previous outbreak in Myanmar in 2010. Phylogenetic analysis of the partial E1 protein revealed that the present (2019) CHIKV strain in Myanmar was closely related to the strain circulating in Thailand in the same year [51].

\section{Conclusions}

As shown in this brief review, CHIKV has emerged as a public health burden and has continued to circulate in South and Southeast Asia over the past decade. CHIKV of the ECSA-IOL genotype, harboring an Ae. albopictus-adaptive mutation (E1: A226V), has been responsible for the large CHIKV epidemics in Asia, especially in rural and suburban areas, since 2005. Recently, the emergence of a novel ECSA with Ae. aegypti-adaptive mutations (E1: K211E and E2: V264A, with E1: 226A) has been reported in many countries, starting around late 2009-2010 in India, which continued circulate and causing the massive outbreak in India in 2016, and Pakistan in 2016 before spreading to Bangladesh in 2017, Thailand in 2018, and Myanmar in 2019. The wide 
distribution of this novel ECSA carrying Ae aegyptiadaptive mutations shows that CHIKV continues to spread at an alarming rate and can expand to new regions through the ever-increasing number of travelers in epidemic areas and adaptations of the strains to local mosquito vectors, particularly in urban areas. The differences between the CHIKV ECSA strains that caused the first mass outbreaks between 2005 and 2015 and the second ones from 2016 to 2020 in South and Southeast Asia suggest that molecular surveillance is necessary to determine the prevalence of viral strains and regional genotype differences, which may lead to a better understanding of virus adaptation, transmission, and outbreak tracking. Furthermore, data for CHIKV outbreak occurrence would aid in developing strategies for the control and prevention of CHIKV infection.

\section{Abbreviations}

CHIKV: Chikungunya virus; ECSA-IOL: East/Central/South African strain-Indian Ocean lineage.

\section{Acknowledgements}

Not applicable.

\section{Authors' contributions}

SK drafted, wrote, and revised the manuscript. SK, JC, and CC have collected information. YP revised and completed the final version of the manuscript. All authors read and approved the final manuscript.

\section{Authors' information}

Dr. Sarawut is a postdoctoral fellow at the Center of Excellence in Clinical Virology, Department of Pediatrics, Faculty of Medicine, Chulalongkorn University in Bangkok. His primary research interests are arboviral diseases, molecular epidemiology, and the evolution of the chikungunya virus.

\section{Funding}

This work was supported by the Research Chair Grant from the National Science and Technology Development Agency (P-15-50004), the Center of Excellence in Clinical Virology of Chulalongkorn University and Hospital, and MK Restaurant Group Public Company Limited. SK is supported by the Second Century Fund (C2F), Chulalongkorn University.

\section{Availability of data and materials}

Not applicable.

\section{Declarations}

Ethics approval and consent to participate

Not applicable.

\section{Consent for publication}

Not applicable.

\section{Competing interests}

The authors declare that they have no competing interests.

\section{Author details}

${ }^{1}$ Center of Excellence in Clinical Virology, Department of Pediatrics, Faculty of Medicine, Chulalongkorn University, Bangkok 10330, Thailand. ${ }^{2}$ Department of Microbiology, Faculty of Medicine, Chulalongkorn University, Bangkok 10330, Thailand. ${ }^{3}$ Tropical Medicine Cluster, Chulalongkorn University, Bangkok 10330, Thailand.
Received: 11 March 2021 Accepted: 21 November 2021

Published online: 02 December 2021

\section{References}

1. Caglioti C, Lalle E, Castilletti C, Carletti F, Capobianchi MR, Bordi L. Chikungunya virus infection: an overview. New Microbiol. 2013:36(3):211-27.

2. Andrei $G$, De Clercq E. Molecular approaches for the treatment of hemorrhagic fever virus infections. Antivir Res. 1993;22(1):45-75.

3. Goupil BA, Mores CN. A review of chikungunya virus-induced arthralgia: clinical manifestations, therapeutics, and pathogenesis. Open Rheumatol J. 2016;10:129-40.

4. Simon F, Javelle E, Cabie A, Bouquillard E, Troisgros O, Gentile G, et al. French guidelines for the management of chikungunya (acute and persistent presentations). Med Mal Infect. 2015;45(7):243-63.

5. Economopoulou A, Dominguez M, Helynck B, Sissoko D, Wichmann O, Quenel $\mathrm{P}$, et al. Atypical Chikungunya virus infections: clinical manifestations, mortality and risk factors for severe disease during the 2005-2006 outbreak on Reunion. Epidemiol Infect. 2009;137(4):534-41.

6. Lima Neto AS, Sousa GS, Nascimento OJ, Castro MC. Chikungunyaattributable deaths: a neglected outcome of a neglected disease. PLoS Negl Trop Dis. 2019;13(9):e0007575.

7. Sam IC, Kamarulzaman A, Ong GS, Veriah RS, Ponnampalavanar S, Chan YF, et al. Chikungunya virus-associated death in Malaysia. Trop Biomed. 2010;27(2):343-7.

8. de Almeida Barreto FK, Montenegro RM Jr, Fernandes VO, Oliveira R, de Araujo Batista LA, Hussain A, et al. Chikungunya and diabetes, what do we know? Diabetol Metab Syndr. 2018;10:32.

9. Schuffenecker I, Iteman I, Michault A, Murri S, Frangeul L, Vaney MC et al. Genome microevolution of chikungunya viruses causing the Indian Ocean outbreak. PLoS Med. 2006;3(7):e263.

10. Charrel RN, Leparc-Goffart I, Gallian P, de Lamballerie X. Globalization of Chikungunya: 10 years to invade the world. Clin Microbiol Infect. 2014;20(7):662-3.

11. Pouriayevali MH, Rezaei F, Jalali T, Baniasadi V, Fazlalipour M, Mostafavi E, et al. Imported cases of Chikungunya virus in Iran. BMC Infect Dis. 2019;19(1):1004.

12. Patil J, More A, Patil P, Jadhav S, Newase P, Agarwal M, et al. Genetic characterization of chikungunya viruses isolated during the 2015-2017 outbreaks in different states of India, based on their E1 and E2 genes. Arch Virol. 2018;163(11):3135-40.

13. Hisamuddin M, Tazeen A, Abdullah M, Islamuddin M, Parveen N, Islam $\mathrm{A}$, et al. Co-circulation of Chikungunya and dengue viruses in dengue endemic region of New Delhi, India during 2016. Epidemiol Infect. 2018;146(13):1642-53.

14. Rahman M, Yamagishi J, Rahim R, Hasan A, Sobhan A. East/Central/ South African genotype in a Chikungunya outbreak, Dhaka, Bangladesh, 2017. Emerg Infect Dis. 2019;25(2):370.

15. Chansaenroj J, Wanlapakorn N, Ngamsaithong C, Thongmee T, Na Nakorn N, Siriyasatien P, et al. Genome sequences of chikungunya virus isolates from an outbreak in southwest Bangkok in 2018. Arch Virol. 2020;165(2):445-50

16. Kraemer MU, Sinka ME, Duda KA, Mylne AQ, Shearer FM, Barker CM, et al. The global distribution of the arbovirus vectors Aedes aegypti and Ae albopictus. Flife. 2015:4:e08347.

17. Lumsden WH. An epidemic of virus disease in Southern Province, Tanganyika Territory, in 1952-53. II. General description and epidemiology. Trans R Soc Trop Med Hyg. 1955;49(1):33-57.

18. Ross RW. The Newala epidemic. III. The virus: isolation, pathogenic properties and relationship to the epidemic. J Hyg (Lond). 1956;54(2):177-91.

19. Marchette NJ, Rudnick A, Garcia R. Alphaviruses in Peninsular Malaysia: II. Serological evidence of human infection. Southeast Asian J Trop Med Public Health. 1980;11:14-23.

20. Sam IC, Chua CL, Rovie-Ryan JJ, Fu JY, Tong C, Sitam FT, et al. Chikungunya virus in Macaques, Malaysia. Emerg Infect Dis. 2015;21(9):1683-5.

21. Powers AM, Brault AC, Tesh RB, Weaver SC. Re-emergence of chikungunya and o'nyong-nyong viruses: evidence for distinct geographical lineages and distant evolutionary relationships. J Gen Virol. 2000;81:471-9. 
22. Powers $\mathrm{AM}$, Logue $\mathrm{CH}$. Changing patterns of chikungunya virus: reemergence of a zoonotic arbovirus. J Gen Virol. 2007;88:2363-77.

23. Staples JE, Breiman RF, Powers AM. Chikungunya fever: an epidemiological review of a re-emerging infectious disease. Clin Infect Dis. 2009:49(6):942-8.

24. Rezza G, Nicoletti L, Angelini R, Romi R, Finarelli AC, Panning M, et al. Infection with chikungunya virus in Italy: an outbreak in a temperate region. Lancet. 2007;370:1840-6.

25. Grandadam M, Caro V, Plumet $S$, Thiberge JM, Souarès Y, Failloux $A B$, et al. Chikungunya virus, southeastern France. Emerg Infect Dis. 2011;17(5):910-3.

26. Hapuarachchi HC, Bandara KB, Sumanadasa SD, Hapugoda MD, Lai $Y L$, Lee KS, et al. Re-emergence of chikungunya virus in South-east Asia: virological evidence from Sri Lanka and Singapore. J Gen Virol. 2010;91:1067-76.

27. Sam IC, Chan YF, Chan SY, Loong SK, Chin HK, Hooi PS, et al. Chikungunya virus of Asian and Central/East African genotypes in Malaysia. J Clin Virol. 2009;46(2):180-3.

28. Kumar NP, Joseph R, Kamaraj T, Jambulingam P. A226V mutation in virus during the 2007 chikungunya outbreak in Kerala, India. J Gen Virol. 2008:89:1945-8

29. Tsetsarkin KA, Chen R, Weaver SC. Interspecies transmission and chikungunya virus emergence. Curr Opin Virol. 2016;16:143-50.

30. Cao-Lormeau VM, Musso D. Emerging arboviruses in the Pacific. Lancet. 2014;384(9954):1571-2.

31. Wimalasiri-Yapa BMCR, Stassen L, Huang X, Hafner LM, Hu W, Devine GJ, et al. Chikungunya virus in Asia-Pacific: a systematic review. Emerg Microbes Infect. 2019;8(1):70-9.

32. Prevention. CfDCa. Chikungunya geographic distribution. CDC Web site. http://www.cdc.gov/chikungunya/geo/index.html Updated 30 Oct 2020.

33. Nhan TX, Musso D. The burden of chikungunya in the Pacific. Clin Microbiol Infect. 2015;21(6):e47-8

34. Musso D, Cao-Lormeau VM, Gubler DJ. Zika virus: following the path of dengue and chikungunya? Lancet. 2015;386(9990):243-4

35. Roth A, Mercier A, Lepers C, Hoy D, Duituturaga S, Benyon E, et al. Concurrent outbreaks of dengue, chikungunya and Zika virus infections - an unprecedented epidemic wave of mosquito-borne viruses in the Pacific 2012-2014. Euro Surveill. 2014;19(41):20929.

36. Arankalle VA, Shrivastava S, Cherian S, Gunjikar RS, Walimbe AM, Jadhav SM, et al. Genetic divergence of Chikungunya viruses in India (19632006) with special reference to the 2005-2006 explosive epidemic. J Gen Virol. 2007:88:1967-76.

37. Dupont-Rouzeyrol M, Caro V, Guillaumot L, Vazeille M, D'Ortenzio E, Thiberge JM, et al. Chikungunya virus and the mosquito vector Aedes aegypti in New Caledonia (South Pacific Region). Vector Borne Zoonotic Dis (Larchmont, NY). 2012;12(12):1036-41.

38. Horwood PF, Reimer $\amalg$, Dagina R, Susapu M, Bande G, Katusele M, et al. Outbreak of chikungunya virus infection, Vanimo, Papua New Guinea. Emerg Infect Dis. 2013;19(9):1535-8.

39. Mombouli JV, Bitsindou P, Elion DO, Grolla A, Feldmann H, Niama FR, et al. Chikungunya virus infection, Brazzaville, Republic of Congo, 2011. Emerg Infect Dis. 2013:19(9):1542-3.

40. Wangchuk S, Chinnawirotpisan P, Dorji T, Tobgay T, Dorji T, Yoon IK, et al. Chikungunya fever outbreak, Bhutan, 2012. Emerg Infect Dis, 2013;19(10):1681-4

41. Wu D, Zhang Y, Zhouhui Q, Kou J, Liang W, Zhang H, et al. Chikungunya virus with E1-A226V mutation causing two outbreaks in 2010, Guangdong, China. Virol J. 2013;10:174

42. Cassadou S, Boucau S, Petit-Sinturel M, Huc P, Leparc-Goffart I, Ledrans M. Emergence of chikungunya fever on the French side of Saint Martin island, October to December 2013. Euro Surveill. 2014:19(13):20752.

43. Nunes MR, Faria NR, de Vasconcelos JM, Golding N, Kraemer MU, de Oliveira LF, et al. Emergence and potential for spread of Chikungunya virus in Brazil. BMC Med. 2015;13:102.

44. Shrinet J, Jain S, Sharma A, Singh SS, Mathur K, Rana V, et al. Genetic characterization of Chikungunya virus from New Delhi reveal emergence of a new molecular signature in Indian isolates. Virol J. 2012;9:100.

45. Eyase F, Langat S, Berry IM, Mulwa F, Nyunja A, Mutisya J, et al. Emergence of a novel chikungunya virus strain bearing the E1:V80A substitution, out of the Mombasa, Kenya 2017-2018 outbreak. PLoS ONE. 2020;15(11):e0241754.

46. Maljkovic Berry I, Eyase F, Pollett S, Konongoi SL, Joyce MG, Figueroa $\mathrm{K}$, et al. Global outbreaks and origins of a chikungunya virus variant carrying mutations which may increase fitness for Aedes aegypti: revelations from the 2016 Mandera, Kenya Outbreak. Am J Trop Med Hyg. 2019:100(5):1249-57.

47. Khongwichit S, Chansaenroj J, Thongmee T, Benjamanukul S, Wanlapakorn N, Chirathaworn C, et al. Large-scale outbreak of chikungunya virus infection in Thailand, 2018-2019. PLoS ONE. 2021;16:e0247314.

48. Agarwal A, Gupta S, Yadav AK, Nema RK, Ansari K, Biswas D. Molecular and phylogenetic analysis of chikungunya virus in Central India during 2016 and 2017 outbreaks reveal high similarity with recent New Delhi and Bangladesh strains. Infect Genet Evol. 2019;75:103940.

49. Carletti F, Marsella P, Colavita F, Meschi S, Lalle E, Bordi L, et al. Fulllength genome sequence of a chikungunya virus isolate from the 2017 autochthonous outbreak, Lazio Region, Italy. Genome Announc. 2017;5(49):e01306-17.

50. Melan A, Aung MS, Khanam F, Paul SK, Riaz BK, Tahmina S, et al. Molecular characterization of chikungunya virus causing the 2017 outbreak in Dhaka Bangladesh. New Microbes New Infect. 2018;24:14-6.

51. Kyaw AK, Tun MMN, Nabeshima T, Soe AM, Thida T, Aung TH, et al. Chikungunya virus infection in blood donors and patients during outbreak, Mandalay, Myanmar, 2019. Emerg Infect Dis. 2020;26(11):2741-5.

52. Kendall C, Khalid H, Muller M, Banda DH, Kohl A, Merits A, et al. Structural and phenotypic analysis of Chikungunya virus RNA replication elements. Nucleic Acids Res. 2019:47(17):9296-312.

53. Khan AH, Morita K, Parquet MDC, Hasebe F, Mathenge EGM, Igarashi A. Complete nucleotide sequence of chikungunya virus and evidence for an internal polyadenylation site. J Gen Virol. 2002;83:3075-84.

54. Weaver SC, Forrester NL. Chikungunya: evolutionary history and recent epidemic spread. Antivir Res. 2015;120:32-9.

55. Volk SM, Chen R, Tsetsarkin KA, Adams AP, Garcia TI, Sall AA, et al. Genome-scale phylogenetic analyses of chikungunya virus reveal independent emergences of recent epidemics and various evolutionary rates. J Virol. 2010;84(13):6497-504.

56. Kariuki Njenga M, Nderitu L, Ledermann JP, Ndirangu A, Logue CH, Kelly $\mathrm{CHL}$, et al. Tracking epidemic Chikungunya virus into the Indian Ocean from East Africa. J Gen Virol. 2008;89:2754-60.

57. Tsetsarkin KA, Vanlandingham DL, McGee CE, Higgs S. A single mutation in chikungunya virus affects vector specificity and epidemic potential. PLoS Pathog. 2007;3(12):e201.

58. Paterson HE, Mclntosh BM. Further studies on the chikungunya outbreak in southern Rhodesia in 1962. II. Transmission experiments with the Aedes furcifer-Taylori group of mosquitoes and with a member of the Anopheles gambiae complex. Ann Trop Med Parasitol. 1964;58:52-5.

59. Jupp PG, McIntosh BM. Aedes furcifer and other mosquitoes as vectors of chikungunya virus at Mica, northeastern Transvaal, South Africa. J Am Mosq Control Assoc. 1990;6:415-20.

60. Diallo M, Thonnon J, Traore-Lamizana M, Fontenille D. Vectors of Chikungunya virus in Senegal: current data and transmission cycles. Am J Trop Med Hyg. 1999;60:281-6.

61. Weaver SC. Evolutionary influences in arboviral disease. Curr Top Microbiol Immunol. 2006:299:285-314.

62. Silva LA, Dermody TS. Chikungunya virus: epidemiology, replication, disease mechanisms, and prospective intervention strategies. J Clin Invest. 2017:127(3):737-49.

63. Horwood PF, Buchy P. Chikungunya. Rev Sci Tech. 2015;34(2):479-89.

64. Thiboutot MM, Kannan S, Kawalekar OU, Shedlock DJ, Khan AS, Sarangan $\mathrm{G}$, et al. Chikungunya: a potentially emerging epidemic? PLoS Negl Trop Dis. 2010;4(4):e623.

65. Dupuis-Maguiraga L, Noret M, Brun S, Le Grand R, Gras G, Roques P. Chikungunya disease: infection-associated markers from the acute to the chronic phase of arbovirus-induced arthralgia. PLoS Negl Trop Dis. 2012. https://doi.org/10.1371/journal.pntd.0001446.

66. Calabrese LH. Emerging viral infections and arthritis: the role of the rheumatologist. Nat Clin Pract Rheumatol. 2008;4:2-3.

67. Teo TH, Lum FM, Claser C, Lulla V, Lulla A, Merits A, et al. A pathogenic role for CD4+T cells during chikungunya virus infection in mice. J Immunol. 2013:190(1):259-69. 
68. Phuklia W, Kasisith J, Modhiran N, Rodpai E, Thannagith M, Thongsakulprasert T, et al. Osteoclastogenesis induced by CHIKV-infected fibroblast-like synoviocytes: a possible interplay between synoviocytes and monocytes/macrophages in CHIKV-induced arthralgia/arthritis. Virus Res. 2013;177(2):179-88.

69. Hoarau JJ, Jaffar Bandjee MC, Krejbich Trotot P, Das T, Li-Pat-Yuen G, Dassa B, et al. Persistent chronic inflammation and infection by chikungunya arthritogenic alphavirus in spite of a robust host immune response. J Immunol. 2010;184(10):5914-27.

70. Chow A, Her Z, Ong EK, Chen JM, Dimatatac F, Kwek DJ, et al. Persistent arthralgia induced by chikungunya virus infection is associated with interleukin-6 and granulocyte macrophage colony-stimulating factor. J Infect Dis. 2011:203(2):149-57.

71. Hussain KM, Lee RC, Ng MM, Chu JJ. Establishment of a novel primary human skeletal myoblast cellular model for chikungunya virus infection and pathogenesis. Sci Rep. 2016;6:21406.

72. Sourisseau M, Schilte C, Casartelli N, Trouillet C, Guivel-Benhassine F, Rudnicka D, et al. Characterization of reemerging chikungunya virus. PLoS Pathog. 2007;3(6):e89.

73. Tang BL. The cell biology of Chikungunya virus infection. Cell Microbiol. 2012;14(9):1354-63.

74. Khongwichit S, Wikan N, Abere B, Thepparit C, Kuadkitkan A, Ubol $S$, et al. Cell-type specific variation in the induction of ER stress and downstream events in chikungunya virus infection. Microb Pathog. 2016;101:104-18.

75. Dhanwani R, Khan M, Bhaskar AS, Singh R, Patro IK, Rao PV, et al. Characterization of Chikungunya virus infection in human neuroblastoma SH-SY5Y cells: role of apoptosis in neuronal cell death. Virus Res. 2012;163(2):563-72.

76. Labadie K, Larcher T, Joubert C, Mannioui A, Delache B, Brochard P, et al. Chikungunya disease in nonhuman primates involves long-term viral persistence in macrophages. J Clin Invest. 2010;120(3):894-906.

77. Wintachai P, Wikan N, Kuadkitkan A, JaimipukT, Ubol S, Pulmanausahakul R, et al. Identification of prohibitin as a Chikungunya virus receptor protein. J Med Virol. 2012;84(11):1757-70.

78. Fongsaran C, Jirakanwisal K, Kuadkitkan A, Wikan N, Wintachai P, Thepparit $C$, et al. Involvement of ATP synthase beta subunit in chikungunya virus entry into insect cells. Arch Virol. 2014;159(12):3353-64.

79. Song H, Zhao Z, Chai Y, Jin X, Li C, Yuan F, et al. Molecular basis of arthritogenic alphavirus receptor MXRA8 binding to chikungunya virus envelope protein. Cell. 2019;177(7):1714-24.e12.

80. Basore K, Kim AS, Nelson CA, Zhang R, Smith BK, Uranga C, et al. CryoEM structure of chikungunya virus in complex with the Mxra8 Receptor. Cell. 2019;177(7):1725-37.e16.

81. Zhang R, Earnest JT, Kim AS, Winkler ES, Desai P, Adams LJ, et al. Expression of the Mxra8 receptor promotes alphavirus infection and pathogenesis in mice and drosophila. Cell Rep. 2019;28(10):2647-58.e5.

82. Silva LA, Khomandiak S, Ashbrook AW, Weller R, Heise MT, Morrison $\mathrm{TE}$, et al. A single-amino-acid polymorphism in Chikungunya virus E2 glycoprotein influences glycosaminoglycan utilization. J Virol. 2014;88:2385-97.

83. Ashbrook AW, Burrack KS, Silva LA, Montgomery SA, Heise MT, Morrison TE, et al. Residue 82 of the Chikungunya virus E2 attachment protein modulates viral dissemination and arthritis in mice. J Virol. 2014:88(21):12180-92.

84. Weber C, Berberich E, von Rhein C, Henß L, Hildt E, Schnierle BS. Identification of functional determinants in the chikungunya virus $\mathrm{E} 2$ protein. PLoS Negl Trop Dis. 2017. https://doi.org/10.1371/journal.pntd.0005318.

85. Tanaka A, Tumkosit U, Nakamura S, Motooka D, Kishishita N, Priengprom $\mathrm{T}$, et al. Genome-wide screening uncovers the significance of $\mathrm{N}$-sulfation of heparan sulfate as a host cell factor for chikungunya virus infection. J Virol. 2017. https://doi.org/10.1128/JVI.00432-17.

86. Gardner CL, Ebel GD, Ryman KD, Klimstra WB. Heparan sulfate binding by natural eastern equine encephalitis viruses promotes neurovirulence. Proc Natl Acad Sci USA. 2011;108(38):16026-31.

87. Zhang W, Heil M, Kuhn RJ, Baker TS. Heparin binding sites on Ross River virus revealed by electron cryo-microscopy. Virology. 2005;332(2):511-8.

88. Roderiquez G, Oravecz T, Yanagishita M, Bou-Habib DC, Mostowski $\mathrm{H}$, Norcross MA. Mediation of human immunodeficiency virus type 1 binding by interaction of cell surface heparan sulfate proteoglycans with the V3 region of envelope gp120-gp41. J Virol. 1995;69(4):2233-9.
89. Watterson D, Kobe B, Young PR. Residues in domain III of the dengue virus envelope glycoprotein involved in cell-surface glycosaminoglycan binding. J Gen Virol. 2012;93(Pt 1):72-82.

90. Gardner CL, Choi-Nurvitadhi J, Sun C, Bayer A, Hritz J, Ryman KD, et al. Natural variation in the heparan sulfate binding domain of the eastern equine encephalitis virus E2 glycoprotein alters interactions with cell surfaces and virulence in mice. J Virol. 2013;87(15):8582-90.

91. Hallak LK, Collins PL, Knudson W, Peeples ME. Iduronic acid-containing glycosaminoglycans on target cells are required for efficient respiratory syncytial virus infection. Virology. 2000;271(2):264-75.

92. Tan CW, Poh CL, Sam IC, Chan YF. Enterovirus 71 uses cell surface heparan sulfate glycosaminoglycan as an attachment receptor. J Virol. 2013;87(1):611-20.

93. Henrik Gad H, Paulous S, Belarbi E, Diancourt L, Drosten C, Kümmerer BM, et al. The E2-E166K substitution restores Chikungunya virus growth in OAS3 expressing cells by acting on viral entry. Virology. 2012;434(1):27-37.

94. Kirui J, Abidine Y, Lenman A, Islam K, Gwon YD, Lasswitz L, et al. The phosphatidylserine receptor TIM-1 enhances authentic chikungunya virus cell entry. Cells. 2021:10:1828.

95. Jemielity S, Wang JJ, Chan YK, Ahmed AA, Li W, Monahan S, et al. TIM-family proteins promote infection of multiple enveloped viruses through virion-associated phosphatidylserine. PLoS Pathog. 2013:9(3):e1003232.

96. Moller-Tank S, Albritton LM, Rennert PD, Maury W. Characterizing functional domains for TIM-mediated enveloped virus entry. J Virol. 2014:88(12):6702-13.

97. Prado Acosta M, Geoghegan EM, Lepenies B, Ruzal S, Kielian M, Martinez MG. Surface (S) layer proteins of Lactobacillus acidophilus block virus infection via DC-SIGN interaction. Front Microbiol. 2019;10:810.

98. Chaaithanya IK, Muruganandam N, Surya P, Anwesh M, Alagarasu K, Vijayachari P. Association of oligoadenylate synthetase gene cluster and DC-SIGN (CD209) gene polymorphisms with clinical symptoms in chikungunya virus infection. DNA Cell Biol. 2016;35(1):44-50.

99. Dudha N, Rana J, Rajasekharan S, Gabrani R, Gupta A, Chaudhary VK, et al. Host-pathogen interactome analysis of Chikungunya virus envelope proteins E1 and E2. Virus Genes. 2015;50(2):200-9.

100. Schnierle BS. Cellular attachment and entry factors for chikungunya virus. Viruses. 2019;11:1078.

101. Burt FJ, Rolph MS, Rulli NE, Mahalingam S, Heise MT. Chikungunya: a re-emerging virus. Lancet. 2012;379(9816):662-71.

102. Weaver SC, Lecuit M. Chikungunya virus and the global spread of a mosquito-borne disease. N Engl J Med. 2015;372:1231-9.

103. Khoury VJ, Camilo PR. Chikungunya virus (CHIKV): what can be expected after the acute phase? Reumatol Clin. 2016;12:1-3.

104. Gordon A, Gresh L, Ojeda S, Chowell G, Gonzalez K, Sanchez N, et al. Differences in transmission and disease severity between 2 successive waves of chikungunya. Clin Infect Dis. 2018;67:1760-7.

105. Cunha RVD, Trinta KS. Chikungunya virus: clinical aspects and treatment-a review. Mem Inst Oswaldo Cruz. 2017;112:523-31.

106. Queyriaux B, Simon F, Grandadam M, Michel R, Tolou H, Boutin JP. Clinical burden of chikungunya virus infection. Lancet Infect Dis. 2008;8:2-3.

107. Retuya TJ, Ting DL, Dacula BD, Lanada JM, Roque VG Jr, Hugo CT, et al. Chikungunya fever outbreak in an agricultural village in Indang, Cavite Philippines. Philipp J Microbiol Infect Dis. 1998;27:93-6.

108. Sissoko D, Moendandze A, Malvy D, Giry C, Ezzedine K, Solet JL, et al. Seroprevalence and risk factors of chikungunya virus infection in Mayotte, Indian Ocean, 2005-2006: a population-based survey. PLoS ONE. 2008. https://doi.org/10.1371/journal.pone.0003066.

109. Watson H, Tritsch SR, Encinales L, Cadena A, Cure C, Ramirez AP, et al. Stiffness, pain, and joint counts in chronic chikungunya disease: relevance to disability and quality of life. Clin Rheumatol. 2020;39(5):1679-86

110. Elsinga J, Gerstenbluth I, van der Ploeg S, Halabi Y, Lourents NT, Burgerhof JG, et al. Long-term chikungunya sequelae in curacao: burden, determinants, and a novel classification tool. J Infect Dis. 2017;216(5):573-81.

111. Marti-Carvajal A, Ramon-Pardo P, Javelle E, Simon F, Aldighieri S, Horvath $\mathrm{H}$, et al. Interventions for treating patients with chikungunya virus infection-related rheumatic and musculoskeletal disorders: a systematic review. PLOS ONE. 2017;12(6):e0179028. 
112. Rodriguez-Morales AJ, Cardona-Ospina JA, Fernanda Urbano-Garzon $\mathrm{S}$, Sebastian H-Z. Prevalence of post-chikungunya infection chronic inflammatory arthritis: a systematic review and meta-analysis. Arthritis Care Res (Hoboken). 2016;68(12):1849-58.

113. Burt F, Chen W, Mahalingam S. Chikungunya virus and arthritic disease. Lancet Infect Dis. 2014;14(9):789-90.

114. Hawman DW, Stoermer KA, Montgomery SA, Pal P, Oko L, Diamond MS, et al. Chronic joint disease caused by persistent chikungunya virus infection is controlled by the adaptive immune response. J Virol. 2013;87(24):13878-88

115. Vairo F, Haider N, Kock R, Ntoumi F, Ippolito G, Zumla A. Chikungunya: epidemiology, pathogenesis, clinical features, management, and prevention. Infect Dis Clin N Am. 2019;33(4):1003-25.

116. Singh A, Jain R. Neurological manifestations of chikungunya in children. Indian Pediatr. 2017;54(3):249.

117. Rampal, Sharda M, Meena H. Neurological complications in chikungunya fever. J Assoc Physicians India. 2007;55:765-9.

118. Rajapakse S, Rodrigo C, Rajapakse A. Atypical manifestations of chikungunya infection. Trans R Soc Trop Med Hyg. 2010;104(2):89-96.

119. Chandak NH, Kashyap RS, Kabra D, Karandikar P, Saha SS, Morey SH, et al. Neurological complications of chikungunya virus infection. Neurol India. 2009;57(2):177-80.

120. Contopoulos-loannidis D, Newman-Lindsay S, Chow C, LaBeaud AD. Mother-to-child transmission of chikungunya virus: a systematic review and meta-analysis. PLoS Negl Trop Dis. 2018;12(6):e0006510.

121. Cerbino-Neto J, Mesquita EC, Amancio RT, Brasil P. Events preceding death among chikungunya virus infected patients: a systematic review. Rev Soc Bras Med Trop. 2020;53:e04312019.

122. Kee AC, Yang S, Tambyah P. Atypical chikungunya virus infections in immunocompromised patients. Emerg Infect Dis. 2010;16(6):1038-40.

123. García-Sastre A, Endy TP. Arboviruses. In: Schaechter M, editor. Encyclopedia of microbiology. 3rd ed. Oxford: Academic; 2009. p. 313-21.

124. Hua C, Combe B. Chikungunya virus-associated disease. Curr Rheumatol Rep. 2017:19:69.

125. Silva MMO, Tauro LB, Kikuti M, Anjos RO, Santos VC, Goncalves TSF, et al. Concomitant transmission of dengue, chikungunya, and Zika viruses in Brazil: clinical and epidemiological findings from surveillance for acute febrile illness. Clin Infect Dis. 2019:69:1353-9.

126. Silva JVJ Jr, Ludwig-Begall LF, Oliveira-Filho EF, Oliveira RAS, DuraesCarvalho R, Lopes TRR, et al. A scoping review of chikungunya virus infection: epidemiology, clinical characteristics, viral co-circulation complications, and control. Acta Trop. 2018;188:213-24.

127. Sam IC, Chua CL, Chan YF. Chikungunya virus diagnosis in the developing world: a pressing need. Expert Rev Anti Infect Ther. 2011;9:1089-91.

128. Lo Presti A, Lai A, Cella E, Zehender G, Ciccozzi M. Chikungunya virus, epidemiology, clinics and phylogenesis: a review. Asian Pac J Trop Med. 2014:7:925-32.

129. Johnson BW, Russell BJ, Goodman CH. Laboratory diagnosis of chikungunya virus infections and commercial sources for diagnostic assays. J Infect Dis. 2016;214(Suppl 5):471-4.

130. Panning M, Grywna K, van Esbroeck M, Emmerich P, Drosten C. Chikungunya fever in travelers returning to Europe from the Indian Ocean region, 2006. Emerg Infect Dis. 2008;14:416-22.

131. Lima M, de Lima RC, de Azeredo EL, Dos Santos FB. Analysis of a routinely used commercial anti-chikungunya IgM ELISA reveals cross-reactivities with dengue in Brazil: a new challenge for differential diagnosis? Diagnostics (Basel). 2021;11:819.

132. Prat CM, Flusin O, Panella A, Tenebray B, Lanciotti R, Leparc-Goffart I. Evaluation of commercially available serologic diagnostic tests for chikungunya virus. Emerg Infect Dis. 2014;20:2129-32.

133. Calisher CH, El-Kafrawi AO, Al-Deen Mahmud MI, Travassos da Rosa AP, Bartz CR, Brummer-Korvenkontio M, et al. Complex-specific immunoglobulin $\mathrm{M}$ antibody patterns in humans infected with alphaviruses. J Clin Microbiol. 1986:23:155-9.

134. Hassing RJ, Leparc-Goffart I, Tolou H, van Doornum G, van Genderen PJ. Cross-reactivity of antibodies to viruses belonging to the Semliki forest serocomplex. Euro Surveill. 2010;15:19588.

135. Álvarez-Argüelles ME, Alba SR, Pérez MR, Riveiro JAB, García SM. Diagnosis and molecular characterization of chikungunya virus infections. Curr Top Negl Trop Dis. 2019. https://doi.org/10.5772/intechopen.86957.
136. Ross RW. A laboratory technique for studying the insect transmission of animal viruses, employing a bat-wing membrane, demonstrated with two African viruses. J Hyg (Lond). 1956:54(2):192-200.

137. Hermon YE. Virological investigations of arbovirus infections in Ceylon, with special reference to the recent chikungunya fever epidemic. Ceylon Med J. 1967;12(2):81-92.

138. Hammon WM, Rudnick A, Sather GE. Viruses associated with epidemic hemorrhagic fevers of the Philippines and Thailand. Science. 1960:131(3407):1102-3.

139. Chastel C. Human infections in Cambodia by the chikungunya virus or an apparently closely related agent. II. Experimental pathological anatomy. Bull Soc Pathol Exot Filiales. 1963;56:915-24.

140. Deller JJ, Russell PK. An analysis of fevers of unknown origin in American soldiers in Vietnam. Ann Inter Med. 1967;66(6):1129-43.

141. Khai Ming C, Thain S, Thaung U, Tin U, Myint KS, Swe T, et al. Clinical and laboratory studies on haemorrhagic fever in Burma, 1970-72. Bull World Health Organ. 1974;51(3):227-35.

142. Pavri KM, Banerjee G, Anderson CR, Aikat BK. Virological and serological studies of cases of haemorrhagic fever in Calcutta: material collected by the Institute of Post-Graduate Medical Education and Research, Calcutta. Indian J Med Res. 1964;52:692-7.

143. Centers for Disease Control (CDC). Chikungunya fever among U.S. Peace Corps volunteers-Republic of the Philippines. MMWR Morb Mortal Wkly Rep. 1986;35:573-4.

144. Porter KR, Tan R, Istary Y, Suharyono W, Sutaryo, Widjaja S, et al. A serological study of chikungunya virus transmission in Yogyakarta, Indonesia: evidence for the first outbreak since 1982. Southeast Asian J Trop Med Public Health. 2004;35:408-15.

145. Halstead SB. Epidemiological studies of Thai haemorrhagic fever, 1962-64. Bull World Health Organ. 1966;35(1):80-1.

146. Bhamarapravati NBS, Russell PK. Encephalitis and pneumonitis due to chikungunya virus: report of a fatal case. J Med Assoc Thai. 1966;49:627-32.

147. Nimmannitya S, Halstead SB, Cohen SN, Margiotta MR. Dengue and chikungunya virus infection in man in Thailand, 1962-1964. I. Observations on hospitalized patients with hemorrhagic fever. Am J Trop Med Hyg. 1969;18(6):954-71.

148. Halstead SB, Udomsakdi S, Scanlon JE, Rohitayodhin S. Dengue and chikungunya virus infection in man in Thailand, 1962-1964. V. Epidemiologic observations outside Bangkok. Am J Trop Med Hyg. 1969;18(6):1022-33

149. Halstead SB, Scanlon JE, Umpaivit P, Udomsakdi S. Dengue and chikungunya virus infection in man in Thailand, 1962-1964. IV. Epidemiologic studies in the Bangkok metropolitan area. Am J Trop Med Hyg. 1969;18(6):997-1021.

150. Padbidri VS, Gnaneswar TT. Epidemiological investigations of chikungunya epidemic at Barsi, Maharashtra state, India. J Hyg Epidemiol Microbiol Immunol. 1979;23(4):445-51.

151. Yergolkar PN, Tandale BV, Arankalle VA, Sathe PS, Sudeep AB, Gandhe SS, et al. Chikungunya outbreaks caused by African genotype, India. Emerg Infect Dis. 2006:12(10):1580-3.

152. Gobbi F, Buonfrate D, Angheben A, Degani M, Bisoffi Z. Emergence and surveillance of chikungunya. Curr Trop Med Rep. 2015:2:4-12.

153. Zeller H, Van Bortel W, Sudre B. Chikungunya: Its history in Africa and Asia and its spread to new regions in 2013-2014. J Infect Dis. 2016;214(Suppl 5):436-40.

154. Renault P, Solet JL, Sissoko D, Balleydier E, Larrieu S, Filleul L, et al. A major epidemic of chikungunya virus infection on Reunion Island, France, 2005-2006. Am J Trop Med Hyg. 2007;77(4):727-31.

155. Josseran L, Paquet C, Zehgnoun A, Caillere N, Le Tertre A, Solet JL, et al. Chikungunya disease outbreak, Reunion Island. Emerg Infect Dis. 2006:12(12):1994-5.

156. Delatte H, Paupy C, Dehecq JS, Thiria J, Failloux AB, Fontenille D. Aedes albopictus, vector of chikungunya and dengue viruses in Reunion Island: biology and control. Parasite (Paris, France). 2008;15(1):3-13.

157. Vazeille M, Moutailler S, Coudrier D, Rousseaux C, Khun H, Huerre M, et al. Two chikungunya isolates from the outbreak of La Reunion (Indian Ocean) exhibit different patterns of infection in the mosquito, Aedes albopictus. PLOS ONE. 2007:2:e1168. 
158. Bagny L, Delatte H, Quilici S, Fontenille D. Progressive decrease in Aedes aegypti distribution in Reunion Island since the 1900s. J Med Entomol. 2009:46:1541-5.

159. Noël H, Rizzo C. Spread of chikungunya from the Caribbean to mainland Central and South America: a greater risk of spillover in Europe? Euro Surveill. 2014;19(28):20855.

160. Shah KV, Gibbs CJ Jr, Banerjee G. Virological investigation of the epidemic of haemorrhagic fever in Calcutta: isolation of three strains of chikungunya virus. Indian J Med Res. 1964;52:676-83.

161. Sarkar JK, Pavri KM, Chatterjee SN, Chakravarty SK, Anderson CR. Virological and serological studies of cases of haemorrhagic fever in Calcutta. Material Collected by the Calcutta School of Tropical Medicine. Indian J Med Res. 1964;52:684-91.

162. Cecilia D. Current status of dengue and chikungunya in India. WHO South-East Asia J Public Health. 2014;3(1):22-6.

163. Kalantri SP, Joshi R, Riley LW. Chikungunya epidemic: an Indian perspective. Natl Med J India. 2006;19(6):315-22.

164. Lahariya C, Pradhan SK. Emergence of chikungunya virus in Indian subcontinent after 32 years: a review. J Vector Borne Dis. 2006;43(4):151-60.

165. de Lamballerie X, Leroy E, Charrel RN, Ttsetsarkin K, Higgs S, Gould EA Chikungunya virus adapts to tiger mosquito via evolutionary convergence: a sign of things to come? Virol J. 2008;5:33.

166. Sreekumar E, Issac A, Nair S, Hariharan R, Janki MB, Arathy DS, et al. Genetic characterization of 2006-2008 isolates of Chikungunya virus from Kerala, South India, by whole genome sequence analysis. Virus Genes. 2010;40(1):14-27

167. Kannan M, Rajendran R, Sunish IP, Balasubramaniam R, Arunachalam N, Paramsivan R, et al. A study on chikungunya outbreak during 2007 in Kerala, south India. Indian J Med Res. 2009:129(3):311-5.

168. Seneviratne SL, Perera J. Fever epidemic moves into Sri Lanka. BMJ. 2006:333(7580):1220-1.

169. Razmy AM. Clinical features of chikungunya infection in Sri Lanka. Asian Pac J Trop Dis. 2014;4(2):131-4.

170. ICDDR, B. First identified outbreak of chikungunya in Bangladesh, 2008. Health Sci Bull. 2009;7:1-6.

171. Institute of Epidemiology, Disease Control and Research (IEDCR). Outbreak. https://iedcr.gov.bd/outbreak. Accessed 10 Oct 2021

172. Khatun S, Chakraborty A, Rahman M, Nasreen Banu N, Rahman MM Hasan SM, et al. An outbreak of chikungunya in rural Bangladesh, 2011. PLoS Negl Trop Dis. 2015;9(7):e0003907.

173. Salje H, Lessler J, Paul KK, Azman AS, Rahman MW, Rahman M, et al. How social structures, space, and behaviors shape the spread of infectious diseases using chikungunya as a case study. Proc Natl Acad Sci USA. 2016;113(47):13420-5.

174. Haque F, Rahman M, Banu NN, Sharif AR, Jubayer S, Shamsuzzaman A, et al. An epidemic of chikungunya in northwestern Bangladesh in 2011. PLOS ONE. 2019;14(3):e0212218.

175. Hassan R, Rahman MM, Moniruzzaman M, Rahim A, Barua S, Biswas $R$, et al. Chikungunya - an emerging infection in Bangladesh: a case series. J Med Case Reports. 2014;8(1):67.

176. Darwish MA, Hoogstraal H, Roberts TJ, Ahmed IP, Omar F. A sero-epidemiological survey for certain arboviruses (Togaviridae) in Pakistan. Trans R Soc Trop Med Hyg. 1983;77(4):442-5.

177. Afzal MF, Naqvi S, Sultan MA, Hanif A. Chikungunya fever among children presenting with nonspecific febrile illness during an epidemic of dengue fever in Lahore, Pakistan. Merit Res J Med Med Sci. 2015;3:69-73.

178. Lam SK, Chua KB, Hooi PS, Rahimah MA, Kumari S, Tharmaratnam M et al. Chikungunya infection-an emerging disease in Malaysia. Southeast Asian J Trop Med Public Health. 2001;32(3):447-51.

179. Ayu SM, Lai LR, Chan YF, Hatim A, Hairi NN, Ayob A, et al. Seroprevalence survey of chikungunya virus in Bagan Panchor, Malaysia. Am J Trop Med Hyg. 2010;83:1245-8.

180. Noridah O, Paranthaman V, Nayar SK, Masliza M, Ranjit K, Norizah I, et al. Outbreak of chikungunya due to virus of Central/East African genotype in Malaysia. Med J Malays. 2007:62(4):323-8.

181. Lim KA, Chan YC, Phoon WO, Hanam E. Dengue-type viruses isolated in Singapore. Bull World Health Organ. 1964;30(2):227-40.

182. Leo YS, Chow ALP, Tan LK, Lye DC, Lin L, Ng LC. Chikungunya outbreak, Singapore, 2008. Emerg Infect Dis. 2009;15(5):836-7.
183. Ng L-C, Tan L-K, Tan C-H, Tan SSY, Hapuarachchi HC, Pok K-Y, et al. Entomologic and virologic investigation of chikungunya, Singapore. Emerg Infect Dis. 2009:15(8):1243-9.

184. Ministry of Health Singapore. Chikungunya fever. In: Communicable disease surveillance in Singapore 2014. Singapore: Ministry of Health: 2014:50-2. https://www.moh.gov.sg/docs/librariesprovider5/resourcesstatistics/reports/vector-borne-zoonotic-diseasesb061cae8c6ef49cd9 8e8869bb00033c6.pdf. Accessed 10 Feb 2021.

185. Rianthavorn P, Prianantathavorn K, Wuttirattanakowit N, Theamboonlers A, Poovorawan Y. An outbreak of chikungunya in southern Thailand from 2008 to 2009 caused by African strains with A226V mutation. Int J Infect Dis. 2010;14(Suppl 3):e161-5.

186. Bureau of Epidemiology, Department of Disease Control, Ministry of Public Health, Thailand. Annual incidence report of Chikungunya virus in Thailand. http://www.boe.moph.go.th/boedb/surdata/disease.php? dcontent $=$ situation\&ds=84. Accessed 17 Feb 2021.

187. Wanlapakorn N, Thongmee T, Linsuwanon P, Chattakul P, Vongpunsawad S, Payungporn S, et al. Chikungunya outbreak in Bueng Kan Province, Thailand, 2013. Emerg Infect Dis. 2014;20(8):1404-6.

188. Pongsiri P, Auksornkitti V, Theamboonlers A, Luplertlop N, Rianthavorn P, Poovorawan Y. Entire genome characterization of Chikungunya virus from the 2008-2009 outbreaks in Thailand. Trop Biomed. 2010;27(2):167-76.

189. Chalaem P, Chusri S, Fernandez S, Chotigeat W, Anguita J, Pal U, et al. Characterization of a Chikungunya virus strain isolated from banked patients'sera. Virol J. 2016;13(1):150.

190. Tun MMN, Thant KZ, Inoue S, Nabeshima T, Aoki K, Kyaw AK, et al. Detection of East/Central/South African genotype of chikungunya virus in Myanmar, 2010. Emerg Infect Dis. 2014;20:1378-81.

191. Chastel C. Human infections in Cambodia by the chikungunya virus or a closely related agent. III. Epidemiology. Bull Soc Pathol Exot Filiales. 1964;57:65-82.

192. Duong V, Andries A-C, Ngan C, Sok T, Richner B, Asgari-Jirhandeh N, et al. Reemergence of chikungunya virus in Cambodia. Emerg Infect Dis. 2012;18(12):2066-9.

193. Quyen NTH, Kien DTH, Rabaa M, Tuan NM, Vi TT, Van Tan L, et al. Chikungunya and Zika virus cases detected against a backdrop of endemic dengue transmission in Vietnam. Am J Trop Med Hyg. 2017;97(1):146-50.

194. Soulaphy C, Souliphone P, Phanthavong K, Phonekeo D, Phimmasine $\mathrm{S}$, Khamphaphongphane B, et al. Emergence of chikungunya in Moonlapamok and Khong districts, Champassak province, the Lao People's Democratic Republic, May to September 2012. Western Pac Surveill Response J. 2013;4(1):46-50.

195. Somlor S, Vongpayloth K, Diancourt L, Buchy P, Duong V, Phonekeo D, et al. Chikungunya virus emergence in the Lao PDR, 2012-2013. PLoS ONE. 2017;12(12):e0189879.

196. Vu Qui D, Nguyen-Thi K-T, Ly QB. Study of anti-Chikungunya antibodies in Vietnamese children in Saigon. Bull Soc Pathol Exot Filiales. 1967;60(14):353-9.

197. Pham Thi KL, Briant L, Gavotte L, Labbe P, Perriat-Sanguinet M, Cornillot $E$, et al. Incidence of dengue and chikungunya viruses in mosquitoes and human patients in border provinces of Vietnam. Parasit Vectors. 2017;10(1):556

198. Campos LE, San Juan A, Cenabre LC, Almagro EF. Isolation of chikungunya virus in the Philippines. Acta Med Philipp. 1969;5:152-5.

199. Centers for Disease Control (CDC). Chikungunya fever among U.S. Peace Corps volunteers-Republic of the Philippines. MMWR Morb Mortal Wkly Rep. 1986;35(36):573-4.

200. Sy AK, Saito-Obata M, Medado IA, Tohma K, Dapat C, Segubre-Mercado E, et al. Molecular characterization of chikungunya virus, Philippines, 2011-2013. Emerg Infect Dis. 2016;22(5):887-90.

201. Kemenkes RI. Profil kesehatan Indonesia tahun 2005. Jakarta: Kementerian Kesehatan Rl; 2007

202. Kanamitsu M, Taniguchi K, Urasawa S, Ogata T, Wada Y, Wada Y, et al. Geographic distribution of arbovirus antibodies in indigenous human populations in the Indo-Australian archipelago. Am J Trop Med Hyg. 1979;28(2):351-63.

203. Hotta S, Aoki H, Samoto S, Yasui T, Kawabe M. Virologic-epidemiological studies on Indonesia. II. Measurement of anti-arbovirus antibodies in sera from residents of Lombok, South Sumatera and West Java, in 
comparison with results concerning sera from residents of Japanese main islands. Kobe J Med Sci. 1970;16(4):215-34.

204. Wuryadi S. Outbreak of Chikungunya virus in Indonesia 1982-1985. Virus Inf Exch Newsl. 1986;3:91.

205. Laras K, Sukri NC, Larasati RP, Bangs MJ, Kosim R, Djauzi, et al. Tracking the re-emergence of epidemic chikungunya virus in Indonesia. Trans $R$ Soc Trop Med Hyg. 2005:99(2):128-41.

206. Harapan H, Michie A, Mudatsir M, Nusa R, Yohan B, Wagner AL, et al. Chikungunya virus infection in Indonesia: a systematic review and evolutionary analysis. BMC Infect Dis. 2019;19(1):243.

207. Parola P, de Lamballerie X, Jourdan J, Rovery C, Vaillant V, Minodier P, et al. Novel chikungunya virus variant in travelers returning from Indian Ocean islands. Emerg Infect Dis. 2006;12(10):1493-9.

208. Huang JH, Yang CF, Su CL, Chang SF, Cheng CH, Yu SK, et al. Imported chikungunya virus strains, Taiwan, 2006-2009. Emerg Infect Dis. 2009;15(11):1854-6.

209. Cherian SS, Walimbe AM, Jadhav SM, Gandhe SS, Hundekar SL, Mishra AC, et al. Evolutionary rates and timescale comparison of Chikungunya viruses inferred from the whole genome/E1 gene with special reference to the 2005-07 outbreak in the Indian subcontinent. Infect Genet Evol. 2009;9(1):16-23.

210. Delisle E, Rousseau C, Broche B, Leparc-Goffart I, L'Ambert G, Cochet A, et al. Chikungunya outbreak in Montpellier, France, September to October 2014. Euro Surveill. 2015;20(17):21108.

211. Jääskeläinen AJ, Kareinen L, Smura T, Kallio-Kokko H, Vapalahti O. Chikungunya virus infections in Finnish travellers 2009-2019. Infect Ecol Epidemiol. 2020;10(1):1798096

212. Lindh E, Argentini C, Remoli ME, Fortuna C, Faggioni G, Benedetti $E_{\text {, }}$ et al. The Italian 2017 outbreak chikungunya virus belongs to an emerging Aedes albopictus adapted virus cluster introduced from the Indian subcontinent. Open Forum Infect Dis. 2018;6(1):ofy321.

213. Pyke AT, McMahon J, Burtonclay P, Nair N, De Jong A. Genome Sequences of Chikungunya Virus strains from Bangladesh and Thailand. Microbiol Resour Announc. 2020. https://doi.org/10.1128/MRA. 01452-19.

214. Rauf M, Fatima Tuz Z, Manzoor S, Mehmood A, Bhatti S. Outbreak of chikungunya in Pakistan. Lancet Infect Dis. 2017;17(3):258.

215. Díaz-Menéndez M, Esteban ET, Ujiie M, Calleri G, Rothe C, Malvy D, et al. Travel-associated chikungunya acquired in Myanmar in 2019. Euro Surveill. 2020;25:5-11.

216. Sumathy K, Ella KM. Genetic diversity of chikungunya virus, India 2006-2010: evolutionary dynamics and serotype analyses. J Med Virol. 2012;84(3):462-70.

217. Taraphdar D, Chatterjee S. Molecular characterization of chikungunya virus circulating in urban and rural areas of West Bengal, India after its re-emergence in 2006. Trans R Soc Trop Med Hyg. 2015;109(3):197-202.

218. Agarwal A, Sharma AK, Sukumaran D, Parida M, Dash PK. Two novel epistatic mutations (E1:K211E and E2:V264A) in structural proteins of Chikungunya virus enhance fitness in Aedes aegypti. Virology. 2016:497:59-68

219. National Vector Borne Disease Control Programme (NVBDCP), Ministry of Health \& Family Welfare, Government of India. Chikungunya situation in India. https://nvbdcp.gov.in/index4.php?lang=1\&level=0\&linkid= 486\&lid=3765. Accessed 10 Feb 2021.

220. Anwar S, Taslem Mourosi J, Khan MF, Ullah MO, Vanakker OM, Hosen MJ. Chikungunya outbreak in Bangladesh (2017): clinical and hematological findings. PLoS Negl Trop Dis. 2020;14(2):e0007466.

221. Kabir I, Dhimal M, Müller R, Banik S, Haque U. The 2017 Dhaka chikungunya outbreak. Lancet Infect Dis. 2017:17(11):1118.

222. Harsha PK, Reddy V, Rao D, Pattabiraman C, Mani RS. Continual circulation of ECSA genotype and identification of a novel mutation I317V in the E1 gene of Chikungunya viral strains in southern India during 2015-2016. J Med Virol. 2020;92(8):1007-12.

223. Shi J, Su Z, Fan Z, Wang J, Liu S, Zhang B, et al. Extensive evolution analysis of the global chikungunya virus strains revealed the origination of CHIKV epidemics in Pakistan in 2016. Virol Sin. 2017:32(6):520-32.

224. Badar N, Salman M, Ansari J, Aamir U, Alam MM, Arshad Y, et al. Emergence of chikungunya virus, Pakistan, 2016-2017. Emerg Infect Dis. 2020;26(2):307-10.

225. Phadungsombat J, Imad H, Rahman M, Nakayama EE, Kludkleeb S, Ponam T, et al. A novel sub-lineage of chikungunya virus East/Central/
South African genotype Indian Ocean Lineage caused sequential outbreaks in Bangladesh and Thailand. Viruses. 2020;12(11):1319.

226. Myanmar Times. Chikungunya reappears after 10 years. 2019. https:// www.mmtimes.com/news/chikungunya-reappears-after-10-years.html. Accessed 11 Oct 2021.

\section{Publisher's Note}

Springer Nature remains neutral with regard to jurisdictional claims in published maps and institutional affiliations.
Ready to submit your research? Choose BMC and benefit from:

- fast, convenient online submission

- thorough peer review by experienced researchers in your field

- rapid publication on acceptance

- support for research data, including large and complex data types

- gold Open Access which fosters wider collaboration and increased citations

- maximum visibility for your research: over $100 \mathrm{M}$ website views per year

At BMC, research is always in progress.

Learn more biomedcentral.com/submissions 